\title{
Oncogene-Induced Reprogramming in Acute Lymphoblastic Leukemia: Towards Targeted Therapy of Leukemia- Initiating Cells
}

\author{
Vincent Fregona ${ }^{\dagger}$, Manon Bayet ${ }^{\dagger}$ and Bastien Gerby *(D) \\ Centre de Recherches en Cancérologie de Toulouse (CRCT), Université de Toulouse, Institut National de la Santé \\ et de la Recherche Médicale (INSERM), UMR-1037, Université Toulouse III Paul Sabatier (UPS), \\ 31100 Toulouse, France; vincent.fregona@inserm.fr (V.F.); manon.bayet@inserm.fr (M.B.) \\ * Correspondence: bastien.gerby@inserm.fr \\ t These authors contributed equally to this work.
}

check for

updates

Citation: Fregona, V.; Bayet, M.;

Gerby, B. Oncogene-Induced

Reprogramming in Acute

Lymphoblastic Leukemia: Towards

Targeted Therapy of Leukemia-

Initiating Cells. Cancers 2021, 13, 5511.

https://doi.org/10.3390/

cancers13215511

Academic Editor: David Wong

Received: 7 October 2021

Accepted: 28 October 2021

Published: 2 November 2021

Publisher's Note: MDPI stays neutral with regard to jurisdictional claims in published maps and institutional affiliations.
Simple Summary: Acute lymphoblastic leukemia is a heterogeneous disease characterized by a diversity of genetic alterations, following a sophisticated and controversial organization. In this review, we present and discuss the concepts exploring the cellular, molecular and functional heterogeneity of leukemic cells. We also review the emerging evidence indicating that cell plasticity and oncogene-induced reprogramming should be considered at the biological and clinical levels as critical mechanisms for identifying and targeting leukemia-initiating cells.

\begin{abstract}
Our understanding of the hierarchical structure of acute leukemia has yet to be fully translated into therapeutic approaches. Indeed, chemotherapy still has to take into account the possibility that leukemia-initiating cells may have a distinct chemosensitivity profile compared to the bulk of the tumor, and therefore are spared by the current treatment, causing the relapse of the disease. Therefore, the identification of the cell-of-origin of leukemia remains a longstanding question and an exciting challenge in cancer research of the last few decades. With a particular focus on acute lymphoblastic leukemia, we present in this review the previous and current concepts exploring the phenotypic, genetic and functional heterogeneity in patients. We also discuss the benefits of using engineered mouse models to explore the early steps of leukemia development and to identify the biological mechanisms driving the emergence of leukemia-initiating cells. Finally, we describe the major prospects for the discovery of new therapeutic strategies that specifically target their aberrant stem cell-like functions.
\end{abstract}

Keywords: oncogene-induced reprogramming; (pre-)leukemic stem cells; cell plasticity; self-renewal; oncogenic transcription factors; acute lymphoblastic leukemia

\section{Introduction}

Cell plasticity is a property required for cell reprogramming. The specification of cellular fate during development and differentiation is a dynamic and evolving process that initiates in stem/progenitor cells. A network of transcription factors controls the balance between the maintenance of stem cell identity and the process of lineage specification. However, somatic cell identity is not fixed and can be modified since cellular reprogramming has been achieved. Especially, the concept of the stability of stem cell function has been challenged by the finding that only the Oct4, Sox2, c-Myc and Klf4 transcription factors are required for the reprogramming of somatic cells into induced pluripotent stem cells (iPS) [1]. Interestingly, these four factors have been shown to be oncogenic in different contexts [2], suggesting a link between cell reprogramming and tumorigenesis. This observation is along the lines of the notion that cancer progression is characterized by the gradual loss of a differentiated state associated with the reprogramming of stem cell-like features. 
Indeed, transcriptional and epigenetic modifications occurring in malignant cells frequently lead to tumor dedifferentiation and the acquisition of stemness features [3] and can be exploited using machine learning approaches to predict the clinical outcome and to identify potential drugs targeting the stemness signature [4]. Thus, cell plasticity, oncogene-induced reprogramming, self-renewal, perturbation of lineage identity and cancer initiation appear to be tightly intertwined and should be considered as critical mechanisms for identifying and targeting the cell-of-origin of cancer.

Self-renewal is defined by the functional property of stem cell populations that undergo symmetric or asymmetric divisions to preserve tissue integrity and homeostasis in normal development. In adult hematopoiesis, sustained self-renewal is a distinctive function of normal hematopoietic stem cells (HSCs) which is tightly controlled by a network of transcription factors [5], whereas committed hematopoietic progenitors are devoid of this stem cell property. Thus, it was originally thought in myeloid malignancies that the biological features of leukemic stem cells (LSCs) come from reminiscent states of normal HSCs in which self-renewal is a central property in the process of leukemia initiation. In particular, pioneering studies in chronic myeloid leukemia (CML) considered that the primary oncogenic event takes place in rare and self-renewing multipotent stem cells [6,7], and established the concept that these cells are prone to transformation because of their unique self-renewal capacity. In acute myeloid leukemia (AML), the notion that leukemia originates from an HSC or a committed progenitor is debated in the field. The phenotypic characterization of LSCs in the original studies led to the idea that AML is organized in a hierarchical pattern, in a way similar to that of normal hematopoiesis and derive from the malignant transformation of a primitive hematopoietic cell [8,9]. Supporting this notion, some murine leukemia models have led to show that AML-initiating mutations occur at the level of HSCs and alter their self-renewal properties [10,11]. However, there is evidence that leukemia-initiating activity can be observed not only in an immature cell population but also in populations corresponding to a range of normal committed progenitors. Indeed, a number of studies brought evidence that more mature progenitors, that normally lack any potential for self-renewal, may be the cells-of-origin in AML [12-16]. Thus, oncogenic transcription factors can destabilize the normal molecular program of target cells, leading to changes in gene expression and to a total or partial loss of the original cell identity.

Defined as the most frequent pediatric cancer, acute lymphoblastic leukemia (ALL) is a multistep disease characterized by the acquisition of diverse genetic alterations that can be classified into more than 20 B-lineage subtypes (B-ALL) and more than 10 T-lineage subtypes (T-ALL). These different oncogenic subgroups are established according to the identity of the first oncogenic event carrying in the leukemic cells [17]. Chemotherapy is efficient at inducing long-term remission in child but is associated with severe side effects and undesirable consequences, including second malignant neoplasms. Indeed, while the 5 -year survival rates now exceed $90 \%$, the most common cause of treatment failure in pediatric ALL remains relapse that occurs in approximately $15-20 \%$ of patients [17]. In addition, the treatment is also limited by indiscriminate toxicity towards normal HSCs. Over the last decade, genome-wide analyses, mainly through next generation sequencing approaches, have been extensively used to draw the genomic landscape and the gene expression profile of ALL patients. As recently reviewed and updated both in T-ALL [18] and B-ALL [19,20], this offered major insights regarding the diversity of oncogenic subtypes associated with altered signaling pathways and led to patient stratification and to the discovery of new therapeutic opportunities. However, although current chemotherapy is efficient at reducing the tumor load by targeting proliferating and metabolically active leukemic cells, the disease relapse points to the presence of resistant cells that escape treatment [21]. Thus, pioneering works and emerging studies converge around the notion that the biological properties of pre-leukemic and/or leukemic stem cells, including oncogene-induced reprogramming, cell plasticity, sustained self-renewal activity, cell-quiescence and drug-resistance, can significantly affect leukemia treatment and should be considered in the search for new and more targeted therapies. 
With a focus on B-ALL and T-ALL, we present in this review previous and current studies exploring the cellular, molecular and functional heterogeneity in leukemic cells from patients. With a particular emphasis on the lymphoid lineage, we also review the engineered mouse models that led to the recognition that a single primary oncogene could be sufficient to confer stem cell-like properties to committed progenitors, converting them to a population of pre-LSCs. Finally, we describe the perspectives for the identification of new therapeutic agents that specifically target their aberrant stem cell-like functions.

\section{Cellular and Molecular Heterogeneity in Acute Leukemia: In Search of Leukemic Stem Cells}

\subsection{The Origin of the Leukemic Stem Cell Concept}

According to several pioneering works [22-27], normal hematopoiesis is a well-known tightly regulated process based on a hierarchical organization in which a small number of multipotent stem cells maintain all of the hematopoietic lineages. Similar to the normal hematopoietic system, the concept of leukemic stem cells (LSCs) supports the idea that leukemic cells are functionally heterogeneous, following a hierarchical model in which only a minor population of LSCs residing are able to initiate and indefinitely maintain the neoplastic tissue. Historically and experimentally built on xenograft transplantations, this concept has come from pioneering studies on AML from Dick's laboratory, which have defined a distinct subpopulation of tumor cells characterized by their capacity to initiate and propagate the disease when transplanted into immunodeficient mice [8,9]. Since this finding, xenotransplantation of human leukemic cells has become the gold standard assay to study LSC activity [28]. Based on an immunophenotypic identification, AML was thus the first hematological malignancy with a reported LSC population within the tumor bulk that sustains the long-term leukemia development. This has been confirmed by a number of subsequent studies describing a rare and specialized population of LSCs enriched in the CD34+CD38-Lineage- fraction from AML patients [29-32]. However, transplantable LSCs from AML samples could also be found in the CD34+CD38+ and CD34- subpopulations, albeit with lower frequency [28,33-35], and therefore could be phenotypically more diverse than originally thought. Despite this controversy, it is still inferred that in contrast to leukemic blasts that have limited self-renewal potentials, LSC-enriched populations reside at the apex of the leukemia hierarchy, are able to sustain long-term tumor growth and constitute an important driver of relapse through their slow division rate that make them resistant to conventional therapies $[28,36]$.

\subsection{Phenotypic and Functional Plasticity in ALL}

The notion of cellular and functional heterogeneity in leukemic cells is of fundamental interest to understand the leukemia initiation and development in patients. Therefore, the hierarchical model of the LSC concept was applied to acute lymphoblastic leukemia, in both B-ALL and T-ALL. In B-ALL, scientists extensively used CD34, CD38 and CD19 markers to explore cellular and functional heterogeneity in leukemic blasts from adult and infant patients, which lead to many controversies [37]. It has originally been proposed that leukemic cells with the HSC-like immunophenotype CD34+CD19- exclusively contained LSCs in both high and standard risk B-ALL $[38,39]$. However, the following investigations demonstrated that self-renewal activity can be enriched in leukemic subpopulations expressing the CD19 marker [40-43], corresponding phenotypically to a range of normal B-cell precursors. Nevertheless, the prospective enrichment of LSCs in B-ALL using the CD34 and CD38 surface markers, associated or not with CD19, led to highly variable results $[37,42-44]$. These controversial conclusions could be explained by the possibility that the majority of blasts among the tumor can sustain leukemia-initiating activity, thus following a stochastic model of B-ALL. Indeed, Vormoor and colleagues challenged the hierarchical stem cell concept by demonstrating using limiting dilution assays (LDAs) that B-ALL cells able to engraft immunodeficient mice are highly frequent and are not restricted to a population with a specific immunophenotype [43,45]. Using 
an in vivo tracking approach by cellular barcoding of B-ALL samples combined with deep sequencing, the same group reported that leukemia-initiating clones are abundant and functionally equipotent, exhibiting a similar ability to reconstitute the disease over serial transplantations [46]. Other investigations by Rieger and colleagues demonstrated at the single-cell level that the expression of CD34 and CD38 markers is a highly plastic and dynamic process at the surface of B-ALL blasts [47], which also could explain the previous discrepancies in using these two markers for the enrichment of LSC activity. In the same line of thought, the loss of CD19 antigen expression at the surface of leukemic cells enabling the tumor to evade chimeric antigen receptor (CAR) immunotherapy $[48,49]$ is a well-known representative example of antigen plasticity and evolved adaptation of leukemic cells upon the treatment. Therefore, the identification of several stable surface markers aberrantly expressed in leukemic cells is critical to follow the disease evolution and to monitor resistant cells $[50,51]$. Together, phenotypic and functional plasticity should be considered in experimental approaches to identify LSC-enriched populations, but also at the clinical level to explain therapy escape mechanisms and B-ALL relapse.

In contrast to B-ALL, there are few published studies of cell populations enriched in LSCs from human T-ALL samples. Nevertheless, original works demonstrated that leukemia-initiating activity can be explored by using in vivo xenografts and in vitro assays [52,53]. The functional heterogeneity in human T-ALL combined with the phenotypic characterization of the LSC compartment has been explored using CD34, CD7 and CD4 surface markers. In particular, the work from Pflumio's group reported that CD34+CD7-CD4fraction from the blood of T-ALL patients does not produce leukemic blasts but undergoes normal hematopoiesis in vitro and after transplantation into immune-deficient mice [54], which is quite similar to what has been observed for the CD34+CD19-CD38- population from B-ALL patients [41,42], and that correspond to the residual and circulating normal hematopoietic stem and progenitor cells (HSPCs). In fact, LSC activity seems to be exclusively present in the CD7+ fraction [54,55], suggesting that T-ALL initiation is triggered in a committed T-cell. Finally, T-ALL development is significantly pronounced after the xenograft of CD7+CD34+ leukemic cell population, as demonstrated in three independent studies [54,56,57]. Interestingly, despite the fact that the CD34 marker seems to be useful to enrich LSC activity from T-ALL samples, immunophenotyping of donor-derived blasts in xenograft samples revealed that CD34+ blasts may lose the CD34 maker after transplantation, and vice versa [57]. This observation suggests that CD34 could be a plastic marker at the surface of T-ALL blasts, as it has been shown at the clonal level in B-ALL [47], and asks about the functional relevance and the correspondence of LSC surface markers between blasts from patients and blasts from patient-derived xenografts (PDX).

Collectively, these studies challenge the hierarchical organization of the stem cell concept in ALL by raising the question of whether surface marker plasticity is connected to functional plasticity within the tumor. Indeed, T-ALL characteristics such as cell-surface immunophenotype, but also dormancy and chemoresistance, are under the influence of the bone marrow (BM) niches, indicating an important cellular and functional plasticity of leukemic cells in response to their in vivo microenvironment [58]. Using ALL xenograft models combined with in vivo cell-division assay, Jeremias and colleagues also addressed this notion by demonstrating that stem cell properties, such as dormancy, treatmentresistance and leukemia-initiating activity, are reversible [59]. In addition, the authors showed that the functional plasticity of dormant clones is dependent of their in vivo environment and suggest that this reversible mechanism could be involved in treatment failure and ALL relapse. The molecular characterization of those dormant and chemoresistant clones recently led to the extraction of a core subset of genes that would help for the risk stratification of ALL patients [60], as previously achieved in AML [61]. Together, these findings raise the importance of considering cellular and functional plasticity in the clinical outcome of ALL patients. This points to the need to focus on the functional mechanisms of leukemic cells, such as self-renewal, cell-quiescence and -resistance, to identify new specific LSC markers. 


\subsection{When Molecular Diversity and Clonal Evolution Meet the LSC Theory}

Accurately addressing the cell-of-origin in leukemic patients using surface markers seems to be obviously limited, not only by the plastic properties of leukemic blasts as previously described, but also by their genetic heterogeneity, which represents a major hallmark of cancers, including ALL [62,63]. Indeed, the development of acute leukemia is a multistep process characterized by the acquisition of accumulated mutations. Consistent with the observation that acute leukemias exhibit a limited number of genetic alterations [64], each mutation can perturb critical cellular functions and their combinatorial interaction would be sufficient to cause leukemia.

Through a cytogenetic approach by multiplex fluorescence in situ hybridization (MFISH), Greaves and colleagues explored in a ground-breaking study the intraclonal genetic architecture of leukemic cells from B-ALL patients. Since the M-FISH approach allows for the detection of up to eight genetic alterations at the single-cell level, the authors provided the first direct evidence for genetic diversity of leukemic cells by establishing phylogenetic trees of clonal evolution within individual patients [65]. Major insights in the composition and the dynamic of subclones in leukemic cells have been also gained through the comparison of the genetic landscape of paired diagnostic and relapse ALL samples, as performed in numerous works [66-75]. Thus, genome-wide studies, including single nucleotide polymorphism (SNP), next generation sequencing (NGS), comparative genomic hybridization (CGH) and multiplex ligation-dependent probe amplification (MLPA) analyses of matched diagnosis-relapse ALL samples, led to an exhaustive characterization of the genetic profile of patients during the evolution of their disease. These integrative approaches helped to establish the complex architecture of individual leukemia and revealed that a relapse may be generated from major, minor or ancestral clones from the initial diagnosis. Remarkably, Mullighan and colleagues demonstrated that more than half of the relapse ALL samples lacked some of the genomic copy number abnormalities (CNAs) present at the diagnosis and acquired new and distinct genetic lesions $[66,75,76]$. This observation indicated that in the majority of ALL cases, relapse leukemic cells have evolved not from the bulk of the diagnosis cells but from a clone that harbored a restricted number of genetic alterations, such as a founding chromosomal translocation. Indeed, while a relapse may be produced from a predominant clone at the diagnosis, the majority of them arise from pre-existing minor subclones highly diluted within the diagnosis sample or from the clonal evolution of an ancestral clone $[66,75,77,78]$.

By the same way of evidence, whole- and targeted-exome sequencing of peripheral blood cells from a large cohort of healthy individuals identified that 10 to $20 \%$ of people aged over 70 harbor pre-leukemic mutations resulting in the dominance of a small number of HSC-derived clones, a process called age-related clonal hematopoiesis (ARCH) $[79,80]$. While these pre-leukemic HSCs still have the capacity to differentiate and produce healthy blood cells, additional mutations can lead to disease progression towards myeloid malignancies such as AML [81]. In addition, ultra-sensitive deep sequencing of targeted genomic regions from AML patients revealed the existence of long-lasting clones carrying pre-neoplastic mutations, referred to as pre-leukemic HSCs hidden within the bulk of the tumor and that serve as a reservoir for disease progression [82-84]. These cells can thus acquire stem cell-like drug resistance mechanisms and by way of consequences, are spared by current treatment and are involved in the disease evolution and relapse. Despite of their low abundance in patients, it has been recently shown using clonal tracking from single-cell transcriptomics that these pre-LSCs exhibit a specific gene expression profile, distinct from that of leukemic cells and of normal HSCs [85].

Since xenotransplantation remains the gold standard assay to evaluate leukemiainitiating activity, the notion that genetic subclones are frequently selected in xenograft models adds a level of complexity to the LSC definition. Nevertheless, tracking leukemic clones in immunodeficient mice not only provides insights into the genetic and clonal architecture of human ALL, but also can be used to isolate resistant and adaptative subclones that participate to disease progression. Indeed, it has been shown that xenograft models 
of T-ALL can recapitulate at the genetic and functional levels to the gain of malignancy observed at relapse of the disease, including aggressiveness and therapy resistance [86]. Consistent with a branched rather than linear evolution, oncogenic trees showed that xenograft and relapse samples had frequently derived from an ancestral pre-leukemic clone, and not from diagnosis cells. Interestingly, in the case of ETV6-RUNX1-induced B-ALL, the putative ancestral pre-leukemic clone harboring the ETV6-RUNX1 fusion only observed at the time of diagnosis does not regenerate neither over serial transplantations nor at the relapse [65]. This finding suggests that although xenografting leukemic cells allow us to explore the genetic progression and the aggressiveness of the disease, it does not represent a relevant approach to expand and isolate ancestral pre-leukemic clones. The branching and multi-clonal evolution model of leukemogenesis has been similarly explored using xenotransplantation approaches in BCR-ABL1 [87] and in MLL-rearranged [88] ALL. Therefore, although debated in the literature $[89,90]$, genetic and clonal variegations should definitely be considered to define LSCs by using transplantation in immunodeficient mice. Through an unprecedented large-scale LDA xenografting approach combined with targeted sequencing, this point was recently clarified by the isolation and the characterization of subclones from diagnosis B-ALL samples responsible for a relapse [91]. These clones, referred to as diagnosis Relapse-Initiating (dRI) clones, can be revealed only in a minor proportion of xenografted mice and display low sensitivity to chemotherapeutic agents. At the molecular level, $\mathrm{dRI}$ clones activate the mitochondria metabolism and unfolded protein response (UPR) [91], two stress molecular pathways that have been described to be critical in the maintenance of stem cell homeostasis and function [92,93].

A better understanding about the dynamic and the selection of leukemic cells during disease progression has also been gained through single-cell developmental classification methods. In particular, Nolan and colleagues developed a single-cell mass cytometry (CyTOF) approach [94] allowing for the simultaneous quantification of up to 35 proteins, including surface markers and intracellular phosphorylated proteins involved in normal and pathological B-cell development $[95,96]$. Using this strategy, they were able to align human B-cell subpopulations into a unified trajectory and to precise their regulatory signaling pathways during early differentiation checkpoints [96]. Built on this expertise and combined to machine learning approaches, they recently established a single-cell classification of human B-ALL at the diagnosis and identified specific features, such as activated mTOR signaling and unresponsive pre-BCR signaling, which were sufficient to predict patient relapse [95]. In addition, Müschen and colleagues recently used single-cell amplicon sequencing combined with a single-cell phosphoprotein analysis to study the interaction of oncogenic lesions in STAT5 and ERK signaling pathways during normal Bcell development and malignant transformation [97]. Using these approaches, the authors showed that the driver mutations in these two pathways are mutually exclusive in human B-ALL, consistent with the segregation of STAT5 and ERK phosphorylation. Moreover, the following functional experiments showed that concurrent oncogenic STAT5 and ERK activation can subvert leukemia development, demonstrating the proof of concept that the reactivation of divergent and conflicting signaling pathways represents a powerful barrier to transformation [97]. Recently, single-cell amplicon sequencing has also been applied in human T-ALL to study their clonal heterogeneity and evolution [98]. Strikingly, this approach allowed for the detection of clinically relevant subclones at diagnosis that evolved to major clones at later disease stages.

Collectively, these studies uncovered a considerable and interconnected subclonal diversity in leukemic cells from ALL patients, resulting from a complex, nonlinear and branching evolutionary pathway. They have also demonstrated that the majority of ALL relapses after chemotherapy arise from persisting and resistant minor clones already existing at the time of diagnosis, which can be revealed using xenograft models. These studies predicted the existence of an ancestral pre-diagnostic clone harboring a minimal set of genetic alterations which is not yet transformed but at the top of the tumoral hierarchy and heterogeneity. In addition to genomic approaches, this set of publications also highlights 
the relevance in using single-cell phosphoprotein analyses to define a precise trajectory of normal and pathological B-cell development and to anticipate the relapse of the disease.

\section{Oncogene-Induced Reprogramming in ALL: Tracking (Pre-)Leukemic Stem Cells}

\subsection{Self-Renewal Property and Lineage Plasticity: Early Events of Leukemogenesis?}

Major insights about the multistep process and the prenatal origin of ALL development have been gained from 25 years of outstanding studies by Greaves and his group, exploring leukemia initiation and progression in monochorionic twins [99]. These studies revealed that chromosomal translocations, in particular ETV6-RUNX1, could be detected in blood cells many years before the leukemia onset, establishing a pre-leukemic sub-clonal compartment. Thus, these pre-leukemic cells contain the founding genetic alteration but do not have the capacity to induce the disease by themselves. Later in life, the acquisition of full complement mutations transforms them into malignant leukemic cells, subject to clonal evolution and selection processes, and leads to the genetic heterogeneity of the tumor bulk at the time of diagnosis [99]. Therefore, it seems to be clear that ETV6-RUNX1 originates prenatally during fetal hematopoiesis and acts as a first oncogenic event in a committed B-cell to induce the emergence of a pre-leukemic clone with altered self-renewal and survival properties [100]. Interestingly, the self-renewing pre-leukemic clone exhibits the combination of surface markers CD34+CD38-CD19+CD10- that corresponds neither to a normal B-cell subpopulation nor to fully transformed leukemic blasts. Together, these findings support the view that self-renewal is an early and obligatory event in leukemia initiation, a specific feature of the cell-of-origin, and differs from the propagating activity of fully transformed leukemic blasts. Obviously, the major limit is that pre-leukemic clones are very infrequent in ALL patients $[65,75]$. Therefore, except in rare cases of paired leukemic and pre-leukemic monochorionic twins [99], exploring their biological properties remains highly challenging.

To tackle this issue, the development of engineered mouse models in which there are activated particular oncogenes in specific lineages is of critical interest. Indeed, transgenic mice represent a valuable tool to understand the biological mechanisms by which a primary oncogene induces the disease and their use opens new challenges and has several perspectives: (i) it allows us to decipher biological mechanisms by which an oncogenic pathway perturbs normal hematopoietic development and reprograms a committed progenitor into a pre-LSC during the disease initiation; (ii) it helps to understand the multistep process of the disease from the pre-leukemic to the leukemic stages by identifying the oncogenic collaborative events driving malignant transformation; (iii) it allows us to explore at the molecular and functional levels the crosstalk between pre-leukemic and leukemic cells with their microenvironment; and (iv) finally, it aims to develop therapies that specifically target markers and/or biological mechanisms involved in leukemia development and resistance (Figure 1).

The use of AML mouse models corroborated that the genetic alterations of transcription factors are early events in leukemia development and can interfere with essential cellular functions of somatic cells. As examples, oncogenes such as MOZ-TIF2 [12], MLLAF9 [13], MLL-ENL [14] or PML-RAR [15,16] were shown to be able to induce AML development when introduced into committed target cells. Precisely, the molecular and cellular characterization of the cell-of-origin from the AML mouse models led to the recognition that these cells can self-renew and exhibit a self-renewal gene signature induced by such oncogenic transcription factors. For example, AML1-ETO and MLL-AF9 disrupt the normal hematopoietic functions by inducing self-renewal activity of myeloid progenitors prior the progression towards overt leukemia [13,101,102]. In the case of MLL-AF9, gene expression arrays have revealed that the oncogene can activate an HSC-like program in committed granulocyte-macrophage progenitors $[13,102]$. However, other oncogenes such as $B C R-A B L p 190$ are unable to confer self-renewal properties to hematopoietic progenitor cells [12]. In these cases, the self-renewal function must be conferred by the targeted cell or by additional genetic alterations. On the other hand, the abrogation of transcription factor 
activity could also result in impaired differentiation and the development of hematopoietic malignancies, such as myelodysplastic syndrome (MDS) and AML. For example, the loss of function mutations of the two important transcription factors RUNX1 and CEBP $\alpha$ have been identified in rare familial hematopoietic disorders involving a predisposition to MDS and AML. Furthermore, murine models with diminished expression of key transcription factors such as JunB, Gata1 and Gata2 have shown to perturb HSC regulation and function, establishing a pre-leukemic state, primed to undergo subsequent AML transformation [103-105]. These observations support the view that the loss of function of key transcription factors can also lead to the emergence of an aberrant pre-leukemic stem cell population prior to clonal transformation.

Leukemia initiation Leukemia progression

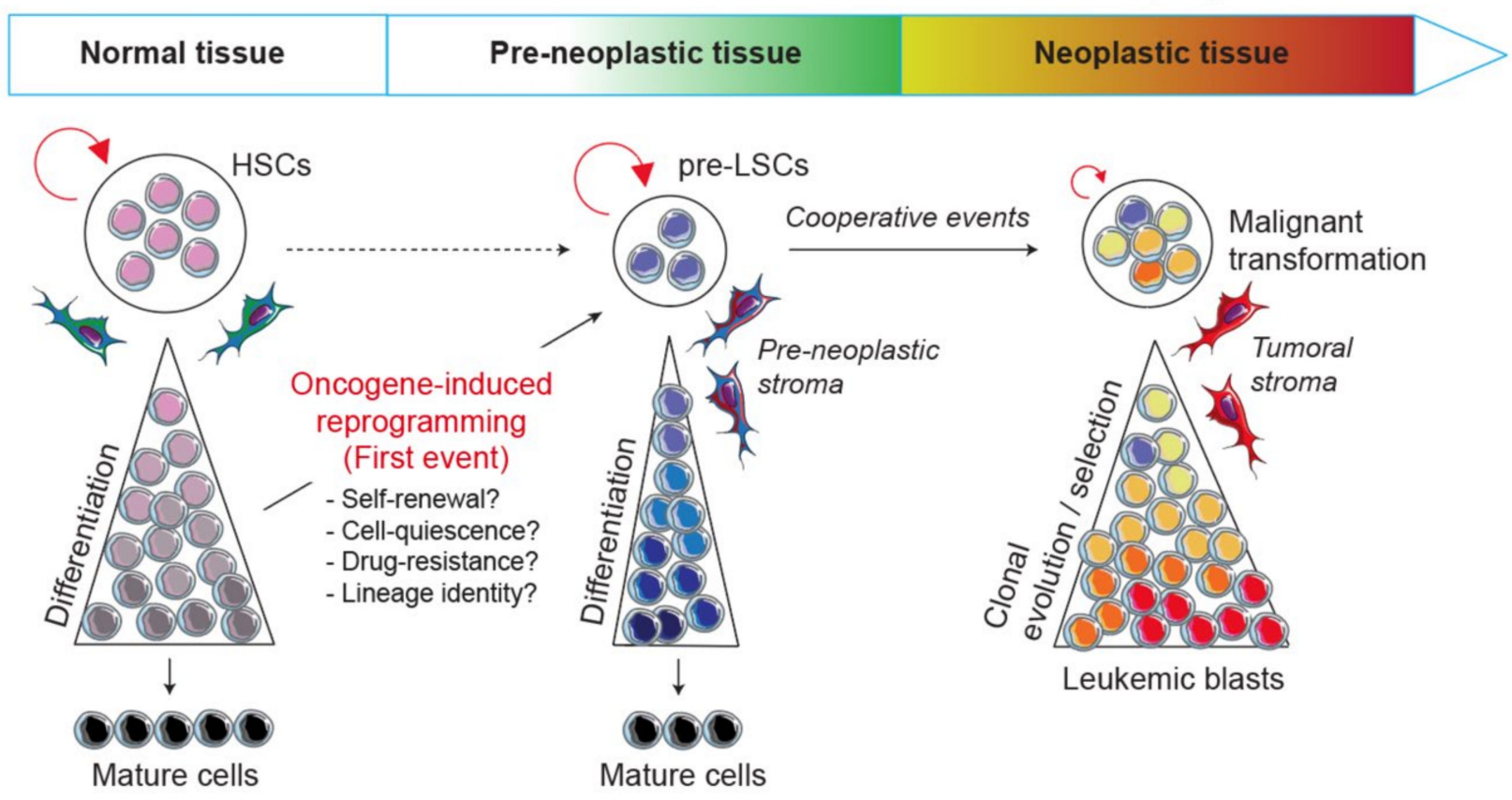

Figure 1. Model of leukemic evolution. A first oncogenic event can either convert a normal HSC or reprogram a normal committed progenitor into a self-renewing pre-LSC. Thus, pre-LSCs are the first cells carrying the initial pre-leukemic lesion but are still able to differentiate and give rise to mature cells. Next, following secondary and cooperative events transform pre-LSCs into malignant leukemic cells that are subjected to clonal evolution and selection processes.

Considering the importance of self-renewal in leukemia initiation, an outstanding question remains how one oncogenic transcription factor can modify or reprogram stem celllike properties in normal cells and can lead to the emergence of a pre-neoplastic population (Figure 1). The occurrence of biphenotypic leukemias and the concept of lineage infidelity in acute leukemias have long been thought of as a degree of plasticity in leukemic cells which either is conferred by the cell-of-origin, such as a pluripotent stem/progenitor, or results from the oncogene subversion of the process of lineage determination in a committed progenitor [106]. This long-lasting idea revives the question of to what extent oncogenic transcription factors in acute leukemias lead to the reactivation of self-renewal genes with or without pluripotency. It also asks to what extent oncogenic alterations that arise in committed progenitors lead to a whole or partial reprogramming of a normal cellular fate and open a new pathologic developmental program. Moreover, the exploration of the cell-of-origin in mixed phenotype acute leukemia (MPAL) led to the idea that a founding alteration, rather than the secondary events, primes pre-leukemic clones for lineage plasticity [107]. 


\subsection{Pre-Leukemic Thymocyte Self-Renewal: Lesson from bHLH Transcription Factors}

In ALL, the demonstration that an oncogenic transcription factor can reprogram a committed progenitor into an aberrant self-renewing pre-LSC has been made for the first time in thymocytes. Since bone marrow-derived progenitors settle in the thymus and gradually lose stemness properties and acquire T-cell characteristics, normal thymocytes have a very limited self-renewal capability [108]. Indeed, thymic output requires continuous seeding from HSCs-derived progenitors, and thymic progenitors progress into the thymus through several stages of differentiation (DN1-4, ISP8, DP) before giving rise to $\mathrm{CD}^{+}$or $\mathrm{CD}^{+}$immunocompetent cells $[109,110]$. Therefore, the thymus represents a relevant cellular platform to study oncogene-induced reprogramming. As assessed by serial transplantation of pre-leukemic thymocytes, McCormack and colleagues reported that the overexpression of the $\mathrm{Lmo} 2$ oncogene in the thymus induces the emergence of a population of pre-LSCs [111]. Precisely, using Cd2-Lmo2 transgenic mouse model that recapitulate the human T-ALL, the study showed that enforced expression of Lmo2 converts normal DN3 thymocytes into a self-renewing, pre-leukemic population by reprogramming a stem cell-like gene program.

LMO proteins, members of the LIM-domain only family, lack the DNA-binding ability and require a protein interaction with basic helix-loop-helix (bHLH) transcription factors such as SCL/TAL1 (SCL) or LYL1 to form a multiprotein complex on DNA and activate the transcription that controls HSPC functions [112]. Based on this molecular evidence, protein-protein interaction should occur between bHLH and LMO1/2 oncoproteins to activate the aberrant stem cell gene program in pre-LSCs. Indeed, Hoang and colleagues showed that the ectopic expression, the interaction and the collaboration of SCL and LMO1 oncoproteins are critical to alter thymocyte differentiation [113] and to induce a self-renewal molecular network for the emergence of pre-LSCs in the thymus $[114,115]$. Therefore, the capacity of SCL-LMO1 to reprogram DN3 thymocytes into self-renewing pre-LSCs mirrors in some aspect the physiological function of SCL, which controls the repopulation ability and the maintenance of HSPCs [116-118]. Furthermore, associated with LMO1, LYL1 ectopic expression mimics the effect of SCL to activate the self-renewal function in pre-LSCs [114], corroborating their functional redundancy described in normal HSCs [119]. In contrast, the loss of function approaches showed that Lyl1, but not Scl, is required for Lmo2-induced thymocyte self-renewal [120]. This observation suggests that Lmo2 oncoprotein interacts preferentially with endogenous Lyl1 than with Scl for thymocyte reprogramming. According to the importance of $S c l$ gene dosage in normal HSPCs [117,118], the alternative explanation would be that the physiological levels of Scl in thymocyte progenitors are not sufficient for its efficient interaction with $\mathrm{Lmo} 2$ oncoprotein.

Cell purification indicates that only DN3 thymocytes in both Lmo2 or SCL-LMO1 mouse models are able to colonize the thymus of recipient mice in transplantation assays [111,114]. The intriguing question then is what predisposes DN3 subsets to reprogramming by these primary oncogenes? The DN3 stage represents a critical restriction point in the thymus when thymocytes are committed to the T-lineage and lose non-T potential under the influence of NOTCH and pre-TCR signaling pathways. Reprogramming self-renewal activity likely occurs just prior to pre-TCR signaling since self-renewal can be induced in $C d 3 \varepsilon^{-/-}$DN3a cells [114]. Thus, while pre-TCR signaling represents a collaborating event in T-ALL progression and transformation [121], it is dispensable for the initial transition from DN3 thymocytes to pre-LSCs. Therefore, NOTCH signaling, which is activated at highest levels in DN3 cells [122], represents a strong candidate to collaborate with $L m o 2$ or SCL-LMO1 oncogenes in thymocyte reprogramming. NOTCH signaling is essential for T-cell commitment and specification [123] but its role in stem cell self-renewal is controversial. Indeed, some studies indicate that NOTCH does not exert an essential function in adult HSCs [124-126], while others suggest that NOTCH activation enhances their self-renewal capacity $[127,128]$. The frequent occurrence of activating mutations of the NOTCH1 gene in T-ALL patients [129] and in mouse models of the disease [110,130], as well as the sensitivity of both human [52,56] and murine leukemic blasts [131] to NOTCH1 
inhibitors, strongly indicates that a gain of function of NOTCH1 represents a critical step in cell transformation. Nonetheless, enforced expression of NOTCH signaling by itself does not convert thymocyte progenitors into pre-LSCs [111,114], comforting the notion that NOTCH1 mutations observed in patients are collaborating and not initiating events in the leukemogenesis process. However, pre-LSC self-renewal induced by SCL-LMO1 collaborates with the physiological levels of the NOTCH-MYC signaling axis [114], which is provided by the cellular interactions with thymic stromal cells. Thus, in contrast to leukemia propagating cells which have acquired different sets of secondary mutations, pre-LSCs are believed to be genetically and phenotypically stable, are still capable of differentiating into mature and functional T-cells and remain highly dependent on their thymic microenvironment [111,114,121].

The major advantage of the transgenic models is to provide unrestricted and reproducible access to pre-LSCs that allow us to study and target their cellular and molecular mechanisms and particularly those involved in therapy resistance. Recent works showed that pre-LSCs are resistant to chemotherapeutic agents because of their distinctive slowdivision rate [132,133]. Indeed, it is well known that cell quiescence may be an important limitation for therapeutic efficiency, as exemplified at the clinical level in CML [134,135]. Using doxycycline-inducible $H 2 B-G F P^{\text {tg }}$ mice, a gold standard in vivo model to study cell quiescence of normal HSCs [136,137], Curtis and colleagues demonstrated that selfrenewal, drug resistance and clonal evolution are restricted to a rare and slow-cycling population of pre-LSCs in the Lmo2-induced T-ALL model [133]. This work not only defines for the first time the importance of the cell cycle restriction in pre-LSC activities, but also makes the H2B-GFP system as a powerful in vivo tool to purify slow-cycling pre-LSCs in other models and to develop strategies targeting the quiescence and the resistance of relapse-inducing clones.

Collectively, this set of publications provided new insights into the long-lasting questions concerning the cell-of-origin of T-ALL and the molecular mechanisms by which oncogenic transcription factors can reprogram the self-renewal property to thymocytes, thus establishing a pre-leukemic state before malignant transformation. These studies demonstrate that the main effect of the transcription factor $\mathrm{SCL}$, associated with its partner $\mathrm{LMO} 1 / 2$, is to induce DN3 thymocyte self-renewal. While thymocyte reprogramming induced by other T-ALL transcription factors such as TLX1, TLX3 or HOXA remains unexplored, emerging studies indicate that chromosomal rearrangements generating NUP98 fusion proteins can induce thymocyte self-renewal prior the DN3 stage $[138,139]$. These observations suggest that only particular cells possess the necessary molecular background to allow for oncogene reprogramming, and conversely, only some oncogenes, in the right cellular context, can induce stem cell-like properties. Despite this, the question of whether a primary oncogene in ALL induces sufficient molecular and functional plasticity to cause lineage subversion remains poorly explored. Interestingly, SCL and LMO2 belong to the five transcription factors that convert adult fibroblasts to multipotent hematopoietic progenitors [140], suggesting their critical functions in cellular and molecular reprogramming of committed cells. Using the generation of targeted mouse lines conditionally expressing Lmo2, two recent studies demonstrate that Lmo2 acts as a "hit-and-run" oncogene in T-ALL development [141,142]. Precisely, while pre-LSC self-renewal activity required continuous Lmo2 expression, overt leukemia frequently evolves in a Lmo2-independent manner [142]. This observation strongly suggests that oncogenic evolution occurring in fully transformed blasts overcomes the requirement of the initiating event. In addition, B-cell-restricted expression of Lmo2 reprograms committed B-cells into malignant T-ALL [141], demonstrating the proof of concept that a primary oncogene can induce sufficient reprogramming to switch from a B-cell fate to a T-cell neoplastic process. The cell-of-origin and the role of the primary oncogene ETV6-RUNX1 in lineage organization have also been addressed recently [143]. Using a lineage-specific oncogenic activation approach, Vicente-Duenas and colleagues demonstrated that ETV6-RUNX1 can give rise to both B-ALL and T-ALL and that leukemia transformation is dependent from the nature of the acquired secondary 
mutations [143]. Although ETV6-RUNX1 is always associated with B-ALL in humans, this strategy predicts that pre-leukemic clones exhibit a T-cell potential. Together, these findings have important implications to develop targeted therapies of pre-LSCs.

\subsection{Cell Reprogramming by PAX5 Mutants: To B-Cells or Not to B-Cells?}

Adult B-cell development is initiated in the BM by the entry of hematopoietic progenitors into the B-cell lineage transcription program and the concomitant sequential rearrangements of the immunoglobulin genes through $\mathrm{V}(\mathrm{D}) \mathrm{J}$ recombination, leading to the generation of immune-competent plasma cells. B-cell development can be dissected into pre-pro- $\mathrm{B}$, pro- $\mathrm{B}$, pre- $\mathrm{B}$, immature $\mathrm{B}$ and mature- $\mathrm{B}$ cell populations corresponding to different stages of differentiation [144]. B-lineage commitment is characterized by the rearrangement of the immunoglobulin heavy-chain $(\mathrm{IgH})$ locus that occurs during the differentiation of pre-pro-B cells to pro-B cells. Productive $\mathrm{V}_{\mathrm{H}}-\mathrm{D}_{\mathrm{H}}-\mathrm{J}_{\mathrm{H}}$ recombination leads to the expression of the Ig $\mu$ protein as part of the pre-B cell receptor (pre-BCR), which promotes the transition from the pro- $\mathrm{B}$ to the pre-B cell stage [145]. Then, successful immunoglobulin light-chain $(I g L)$ gene rearrangement in pre-B cells results in the emergence of immature $\operatorname{IgM}^{+} B$ cells that emigrate from the BM to peripheral lymphoid organs [146]. B-cell lineage is generated from HSCs by a complex and tightly regulated differentiation processes. Among them, the PAX5 gene encodes the crucial transcription factor PAX5, which has been described as the guardian of B-cell identity $[147,148]$. Indeed, while the developmental progression from early B progenitors to plasma cells is regulated by several extracellular signals and transcription factors [149], PAX5 is considered as a master piece to control the irreversible commitment of lymphoid progenitors to the B-cell lineage by activating the transcription of B-cell-specific programs and by suppressing alternative lineage choices $[147,150,151]$. The initial work demonstrated that B-cell differentiation is completely blocked at the transition between pre-pro-B and pro-B stages in $\mathrm{Pax}^{-/-}$mice, revealing the critical role of Pax5 in the B-cell commitment [152]. Then, functional experiments, including transplantation assays, revealed that $\operatorname{Pax}^{-/-}$B-cells had the ability to home in on the BM, where they exhibited aberrant engraftment activity [153]. In addition, uncommitted $\operatorname{Pax}^{-/-}$B-cells are able to differentiate into several hematopoietic cell types, either in vitro in the presence of appropriate cytokines or in vivo after transplantation [147,153-155]. Finally, Pax5 inactivation in mature B-cells leads to the downregulation of B-cell-specific genes and the reactivation of lineage-inappropriate genes [156-158]. This process allowed for their conversion into functional $\mathrm{T}$ cells exhibiting $\operatorname{IgH}$ and $\operatorname{IgL}$ gene rearrangements by dedifferentiation back to early uncommitted progenitors [159]. Interestingly, the loss of lineage identity by the elimination of Pax5 in mature B-cells is also associated with an increased risk of lymphoma development [159]. Together, these findings highlight the critical role of Pax5 in B-lineage commitment and in maintaining the B-cell identity. Given the importance of normal Pax5 in the B-cell development and the degree of plasticity of committed B-cells, the question of whether and to what extent genetic alterations involving PAX5 could reprogram B-cell progenitors and perturb their identity and function remain to be fully explored.

PAX5 is a well-known haploinsufficient tumor suppressor gene in human B-ALL. Indeed, heterozygous deletions of PAX5 are found in about one-third of patients [160-162]. These alterations, which are considered as secondary events in B-ALL development, result in the reduction of PAX5 expression or impairment of DNA-binding activity and/or transcriptional activity of PAX5. However, Pax5 heterozygous mice exhibit normal B-cell development and is not sufficient to induce leukemia in the absence of other oncogenic lesions [163]. The tumor suppressor role of Pax5 has been revealed in these mice using chemical-induced mutagenesis approaches [164]. In addition, the Pax5 tumor-suppressor activity has been demonstrated through the modulation of other critical transcription factors, such as Ebf1 [165,166], Ikzf1 [167] and Stat5 [168]. Since genetic lesions of PAX5, EBF1 and IKZF1 are commonly found in human B-ALL, it suggests that the dosage of these three genes is critical to prevent the disease $[169,170]$. Interestingly, combined 
heterozygous deletion of Pax 5 and Ebf1 partially blocks the differentiation of pro-B cells and increases their lineage plasticity before the leukemia onset $[165,166,171]$. Indeed, $\mathrm{Pax}^{+/-} \mathrm{Ebf1}^{+/-}$pro-B cells downregulated critical genes for the preservation and the stability of the B-cell identity, revealing their response to NOTCH signaling and their T-cell potential in vitro and in vivo. Although the authors did not detect any sign of dedifferentiation into classical hematopoietic progenitors, they demonstrated in this study that simultaneous reduction of Pax5 and Ebf1 induces at the molecular and functional levels a process of lineage conversion in pre-leukemic pro-B cells [171]. Interestingly, molecular reprogramming has been also observed in Ikzf1 [172] deficient mouse models before the leukemia onset. Thus, these studies reinforce the notion that reprogramming, a partial loss of B-cell identity and leukemia initiation are critical mechanisms involved in pre-leukemic cells prior to malignant transformation. Interestingly, recent works from Sanchez-Garcia and colleagues demonstrated that leukemia initiation and progression can be triggered upon natural infection exposure [173,174] or by altering the gut microbiome [175] in Pax5 heterozygous mice as well as in the Sca1-ETV6-RUNX1 model. Indeed, the production of inflammatory cytokines triggered by infection can promote leukemia growth in $\mathrm{Pax} 5^{+/-}$ mice [176]. These studies strongly support the epidemiological evidence suggesting that patterns of infection and inflammation after birth have a causal role in triggering the acquisition of full complement mutations in pre-neoplastic cells to transform them into malignant leukemia [99]. Indeed, emerging evidence demonstrates that a major driver for the conversion from a pre-leukemic clone to fully transformed B-ALL is the exposure to immune stressors, which currently represent a major therapeutic opportunity in the field [177].

PAX5 is also rearranged in $2.6 \%$ of pediatric B-ALL cases, being fused to a wide diversity of fusion partners involving other transcription factors such as ETV6 and FOXP1, chromatin regulators such as NCoR1 and BRD1, a protein kinase such as JAK2 and an estrogen-related receptor such as ESRRB [160,178-181]. All PAX5 fusion proteins conserve the N-terminal DNA-binding paired domain of PAX5 and lack the C-terminal domain, including the transactivation domain $[160,180]$. Chromosomal translocations involving PAX5 have been associated with a blockage of B-cell differentiation, the first reported and frequent example being PAX5-ETV6, which fuses the PAX5 paired domain to almost the entire ETV6 transcription factor [182]. In contrast to PAX5 deletions, PAX5 translocations act as primary oncogenic events, altering normal B-cell development in the early steps of the disease. Therefore, PAX5 fusion proteins represent strong candidates to reprogram stem cell features in B-cell progenitors. However, studying their role in leukemia development is highly limited by the lack of animal models. Exhaustively, transgenic mice expressing PAX5-ETV6 and PAX5-FOXP1 fusion proteins from the Pax5 locus have been generated. While they failed to induce B-ALL on their own, both fusion proteins blocked the B-cell development at the pro-B/pre-B cell transition [183]. Recently, our group developed a new genetically engineered mouse model of B-ALL induced by PAX5-ELN [184], a fusion protein previously identified in patients [179]. Driven by the IgH locus, PAX5-ELN efficiently induced the B-ALL in mice associated with the acquisition of secondary mutations in genes involved in the JAK/STAT and RAS/MAPK pathways, which are recurrently found in B-ALL patients [162] and in other oncogene-induced B-ALL models such as ETV6RUNX1 [185] and TCF3-PBX1 [186] transgenic mice. Thus, these transgenic mice accurately reproduce the key features of leukemia development and provide a valuable in vivo model mimicking the multistep process of human B-ALL. Importantly, the leukemia development is preceded by three months of a pre-leukemic phase which is also associated with a partial blockade of differentiation at the transition of pro-B/pre-B stages. Thus, our in vivo model opens the way for deciphering the biological mechanisms by which a PAX5 fusion protein reprograms normal B-cell progenitors, perturbs B-cell identity and leads to the emergence of pre-LSCs. In addition, it should help us to explore the molecular and the functional crosstalk between pre-LSCs and their BM niches. 
Point mutations of PAX5 are found in about 7\% of both adult and childhood BALL [161,162]. Somatic mutations of PAX5 are a hallmark of B-ALL [161,162] and inherited PAX5 mutations have also been reported $[187,188]$. In contrast to PAX5 translocations that lead to the loss of trans-activating/inhibitory domains and conserves the integrity of the DNA-binding domain, PAX5 point mutations are predicted to result in lost or altered DNAbinding or transcriptional regulatory functions [162,189]. The somatic mutation P80R of PAX5 (PAX5-P80R) was recurrently identified within the exon 3 encoding the paired DNAbinding domain and represents the most frequent PAX5 point mutation $[161,162]$. Recently, it has been shown that the PAX5-P80R mutation induces a unique transcriptional program in patients, defining an independent B-ALL subtype and supporting the notion that PAX5$P 80 R$ is an initiating lesion in the process of leukemogenesis [190-193]. However, the question of whether PAX5 mutations and PAX5 fusion proteins exhibit different molecular mechanisms in driving B-ALL remains unanswered. Therefore, comparing the effect of PAX5 fusion proteins and PAX5 mutations on B-cell reprograming and B-cell identity should bring novel insight on the general biological mechanisms required for normal and pathological B-cell development.

\section{Murine Models as Tools to Explore the Multistep Process of ALL}

As documented in the previous sections, murine models represent valuable tools to explore oncogene-induced reprogramming that occurs in the early step of leukemia development. Furthermore, their use has greatly contributed to understanding the natural history of the human disease from the pre-leukemic state to the following fully transformed stages. Here, we review and update the mouse models that have been developed for mimicking the multistep process of leukemia development both in T-ALL and B-ALL. Thus, we summarize the mouse strains that have been used to study the impact of the inappropriate expression of an oncogenic transcription factor on pre-leukemic T- or B-cell lineages, and to identify their associated collaborative events driving malignant transformation (Table 1). 


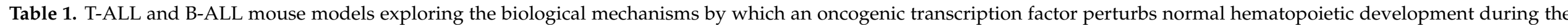
pre-leukemic phase and leads to malignant transformation.

\begin{tabular}{|c|c|c|c|c|}
\hline Transgene & Additional Modifications & $\begin{array}{l}\text { Pre-Leukemic State/ } \\
\text { Reprogramming }\end{array}$ & $\begin{array}{l}\text { Disease Evolution/ } \\
\text { Collab. Events }\end{array}$ & Ref. \\
\hline \multicolumn{5}{|l|}{ T-ALL mouse models } \\
\hline \multicolumn{5}{|l|}{$\begin{array}{l}\text { bHLH transcription factors and } \\
\text { partners }\end{array}$} \\
\hline $\begin{array}{c}\text { Scl } \\
\text { (pSil, Cd2 or Sca1 promoters) }\end{array}$ & - & Perturb T-cell differentiation & No leukemia & [194-196] \\
\hline Scl (Lck promoter) & - & Perturb T-cell differentiation & T-ALL (low penetrance) & \multirow{3}{*}[131,197-199]{} \\
\hline Lmo2 (Lck promoter) & - & Perturb T-cell differentiation & T-ALL (low penetrance) & \\
\hline Scl-Lmo2 (Lck promoters) & - & Expansion of DN3/DN4 populations & $\begin{array}{l}\text { T-ALL ( } \sim 3 \text { months) } \\
\text { Notch1 mutations }\end{array}$ & \\
\hline \multirow{6}{*}{$\begin{array}{c}\text { Lmo2 } \\
(C d 2 \text { promoter })\end{array}$} & - & $\begin{array}{c}\text { Pre-leukemic DN3 thymocyte self-renewal } \\
\text { (pre-LSCs) } \\
\text { ETP-ALL-like molecular signature }\end{array}$ & $\begin{array}{l}\text { T-ALL ( 10 months) } \\
\text { NOTCH1 and Dnm2 mutations }\end{array}$ & {$[111,133,200]$} \\
\hline & $\mathrm{Scl}^{\Delta /-}$ or $\mathrm{Lyl1}^{-/-}$ & Lyl1, but not Scl, required for pre-LSC self-renewal & Lyl1 is required for T-ALL development & [120] \\
\hline & $\mathrm{Hhex}^{\Delta /-}$ or $\mathrm{Kit}^{\mathrm{Wv} / \mathrm{Wv}_{\mathrm{v}}}$ & $\begin{array}{l}\text { Hhex regulates Kit to promote radioresistance and } \\
\text { pre-LSC self-renewal }\end{array}$ & $\begin{array}{l}\text { Hhex and Kit are not required for T-ALL } \\
\text { development }\end{array}$ & [201] \\
\hline & $\mathrm{Dnm} 2^{\mathrm{V} 235 \mathrm{G}}$ & Restore cycling and survival of pre-LSCs & Accelerate T-ALL progression & [200] \\
\hline & $\begin{array}{c}\text { H2B-GFP } \\
\text { (Tet-on system) }\end{array}$ & $\begin{array}{l}\text { Identification of chemo-resistant and cell } \\
\text { cycle-restricted pre-LSCs }\end{array}$ & $\begin{array}{c}\text { Cell cycle restriction is critical for clonal } \\
\text { evolution }\end{array}$ & \multirow{2}{*}{ [133] } \\
\hline & H2B-GFP Cdkn1a-/- & $\begin{array}{l}\text { Loss of asymmetric cell division and cell cycle } \\
\text { restriction }\end{array}$ & Reduce T-ALL progression & \\
\hline $\begin{array}{c}\text { Lmo2 } \\
\text { (Tet-off system) }\end{array}$ & - & Lmo2 expression required for pre-LSC self-renewal & $\begin{array}{c}\text { Lmo2-independent T-ALL development }(\sim 12 \\
\text { months) } \\
I k z f 1 \text { deletions }\end{array}$ & [142] \\
\hline $\begin{array}{c}\text { Lmo2 } \\
\text { (Cre-driving Rosa26 promoter) }\end{array}$ & - & $\begin{array}{l}\text { Lmo2 reprograms committed B-cells into } \\
\text { malignant T-ALL }\end{array}$ & Lmo2: “hit-and-run” oncogene in T-ALL & [141] \\
\hline
\end{tabular}


Table 1. Cont.

\begin{tabular}{|c|c|c|c|c|}
\hline Transgene & Additional Modifications & $\begin{array}{l}\text { Pre-Leukemic State/ } \\
\text { Reprogramming }\end{array}$ & $\begin{array}{l}\text { Disease Evolution/ } \\
\text { Collab. Events }\end{array}$ & Ref. \\
\hline \multirow{3}{*}{$\begin{array}{c}\text { SCL-LMO1 } \\
\text { (pSil and Lck promoters, respectively) }\end{array}$} & - & $\begin{array}{c}\text { Impaired T-cell differentiation } \\
\text { Pre-leukemic DN3a thymocyte self-renewal } \\
\text { (pre-LSCs) } \\
\text { Activation of a stem cell gene signature } \\
\text { Pre-LSCs low proliferation rate and } \\
\text { chemosensitivity }\end{array}$ & $\begin{array}{l}\text { T-ALL ( 4 months) } \\
\text { NOTCH1 mutations }\end{array}$ & {$[113,114,121,132]$} \\
\hline & $\begin{array}{c}\text { NOTCH1 } \\
\text { (Lck promoter) }\end{array}$ & $\begin{array}{c}\text { Enhance pre-LSC self-renewal } \\
\text { Expand the pool of pre-LSC to DN1-4 and ISP8 } \\
\text { populations }\end{array}$ & Accelerate T-ALL progression ( 1 month) & \multirow{2}{*}[114,121]{} \\
\hline & $\begin{array}{c}\mathrm{Cd} 3 \varepsilon^{-/-} \text {and NOTCH1 } \\
\mathrm{Cd} 3 \varepsilon^{-/-}\end{array}$ & Pre-TCR dispensable for pre-LSC self-renewal & Pre-TCR required for T-ALL development & \\
\hline $\begin{array}{c}\text { LYL1-LMO1 } \\
\text { (Lck promoters) }\end{array}$ & - & Pre-leukemic DN3 thymocyte self-renewal & ND & [114] \\
\hline \multicolumn{5}{|l|}{ Fusion proteins } \\
\hline \multirow[t]{2}{*}{$\begin{array}{l}\text { NUP98-HOXD13 } \\
\text { (Vav promoter) }\end{array}$} & - & $\begin{array}{l}\text { Pre-leukemic DN2 thymocyte self-renewal } \\
\text { (pre-LSCs) } \\
\text { Overexpression of HOXA cluster genes }\end{array}$ & MDS/AML (mostly)/T-ALL ( 15\%) & \multirow[t]{2}{*}[138,202]{} \\
\hline & Lyl1 $^{-/-}$ & Lyl1 required for pre-LSC self-renewal & T-ALL $(100 \%)$ & \\
\hline \multicolumn{5}{|l|}{ B-ALL mouse models } \\
\hline \multicolumn{5}{|l|}{ Pax5 dosage } \\
\hline $\operatorname{Pax} 5^{-/-}$ & - & $\begin{array}{l}\text { Blockade at pre-pro-B stage }\left(\mathrm{B} 220^{+} \mathrm{CD} 19^{-} \mathrm{Kit}^{+}\right) \\
\text {Self-renewal activity, multilineage potential }\end{array}$ & No leukemia & {$[147,153]$} \\
\hline $\begin{array}{c}\operatorname{Pax} 5^{\Delta /-} \\
\text { (Cre-mediated deletion) }\end{array}$ & - & $\begin{array}{c}\text { Lineage plasticity and dedifferentiation of mature } \\
\text { B-cells } \\
\text { Conversion of B-cells into BCR-rearranged } \\
\text { functional T-cells }\end{array}$ & B-cell lymphoma & [159] \\
\hline
\end{tabular}


Table 1. Cont.

\begin{tabular}{|c|c|c|c|c|}
\hline Transgene & Additional Modifications & $\begin{array}{l}\text { Pre-Leukemic State/ } \\
\text { Reprogramming }\end{array}$ & $\begin{array}{l}\text { Disease Evolution/ } \\
\text { Collab. Events }\end{array}$ & Ref. \\
\hline \multirow{5}{*}{$\operatorname{Pax}^{+/-}$} & - & No differentiation blockade & No leukemia & {$[163,203]$} \\
\hline & $\begin{array}{l}\text { Chemical (ENU) or retroviral } \\
\text { (MMLV) mutagenesis }\end{array}$ & - & $\begin{array}{c}\text { B-ALL ( } \sim 6 \text { to } 8 \text { months }) \\
\text { Pax5 and Ikzf1 deletions, Jak1 and Jak3 } \\
\text { mutations }\end{array}$ & [164] \\
\hline & $\begin{array}{l}\text { Infection exposure or } \\
\text { microbiome disturbance }\end{array}$ & - & $\begin{array}{l}\text { B-ALL ( } \sim \text { to } 16 \text { months) } \\
J A K 3 \text {, Stat } 5 b \text { and } \operatorname{Pax} 5 \text { mutations }\end{array}$ & [173-175] \\
\hline & $\mathrm{Ebf1}^{+/-} \mathrm{Ikzf1}^{+/-}$ & - & $\begin{array}{l}\text { B-ALL }(40 \%) \\
\text { T-ALL }(35 \%)\end{array}$ & [204] \\
\hline & CA-Stat5b & - & B-ALL ( 2 months) & [168] \\
\hline \multicolumn{5}{|l|}{ Pax5 mutations } \\
\hline Pax5 P80R & $-\mathrm{Pax} 5^{\mathrm{P} 80 \mathrm{R} / \mathrm{P} 80 \mathrm{R}}$ & - & $\begin{array}{l}\text { B-ALL ( 3 months) } \\
\text { Jak1 and Jak3 mutations }\end{array}$ & {$[190]$} \\
\hline \multirow[b]{2}{*}{ PAX5 Y351* } & $-\mathrm{Pax} 5^{\mathrm{Y} 351^{*} /+}$ & - & B-ALL ( 25 months) & \multirow[b]{2}{*}[205]{} \\
\hline & $-\operatorname{Pax} 5^{\mathrm{Y} 351^{*} / \mathrm{Y} 351^{*}}$ & - & $\begin{array}{c}\text { B-ALL ( 8 months) } \\
\text { Jak3 and Ptpn11 mutations }\end{array}$ & \\
\hline \multicolumn{5}{|l|}{ Pax5 rearrangements } \\
\hline \multirow{2}{*}{$\begin{array}{l}\text { PAX5-ETV6 } \\
\text { (Pax5 promoter) }\end{array}$} & - & Blockade between pro-B/pre-B cells & B-ALL $(<10 \%)$ & \multirow{2}{*}[183]{} \\
\hline & Cdkn2ab ${ }^{+/-}$ & - & B-ALL ( $\sim 6$ months) & \\
\hline $\begin{array}{l}\text { PAX5-ELN } \\
\text { (IgH enhancer) }\end{array}$ & - & $\begin{array}{c}\text { Partial blockage at pro-B stage } \\
\text { Aberrant expansion potential of pre-leukemic } \\
\text { pro-B }\end{array}$ & $\begin{array}{c}\text { B-ALL ( 6 months) } \\
\text { Ptpn11, Kras, Jak3 and Pax5 mutations }\end{array}$ & [184] \\
\hline
\end{tabular}


Table 1. Cont.

\begin{tabular}{|c|c|c|c|c|}
\hline Transgene & Additional Modifications & $\begin{array}{l}\text { Pre-Leukemic State/ } \\
\text { Reprogramming }\end{array}$ & $\begin{array}{l}\text { Disease Evolution/ } \\
\text { Collab. Events }\end{array}$ & Ref. \\
\hline \multicolumn{5}{|l|}{ Other rearrangements } \\
\hline \multirow{2}{*}{$\begin{array}{l}\text { ETV6-RUNX1 } \\
\text { (Etv6 promoter) }\end{array}$} & - & & No leukemia & \multirow[b]{2}{*}{ [185] } \\
\hline & $\begin{array}{l}\text { Sleeping beauty }(\mathrm{SB}) \\
\text { transposon system }\end{array}$ & - & $\begin{array}{l}\text { B-ALL ( } \sim 6 \text { months) } \\
\text { Jak1 and Jak3 mutations }\end{array}$ & \\
\hline \multirow{2}{*}{$\begin{array}{l}\text { ETV6-RUNX1 } \\
\text { (Sca1 promoter) }\end{array}$} & - & - & No leukemia & \multirow[b]{2}{*}[175,206]{} \\
\hline & $\begin{array}{l}\text { Infection exposure or } \\
\text { microbiome disturbance }\end{array}$ & Perturb B-cell development & B-ALL ( 11\%) & \\
\hline $\begin{array}{c}\text { ETV6-RUNX1 } \\
\text { (Cre-driving Etv6 promoter) }\end{array}$ & - & $\begin{array}{c}\text { Pre-leukemic ETV6-RUNX1 HSPC } \\
\text { (Sca1-Cre/Infectious stimuli) } \\
\text { Propensity to trigger T and B malignancies }\end{array}$ & $\begin{array}{c}\text { B-ALL (Pax5 mutations) } \\
\text { T-ALL (NOTCH1 and Bcl11b mutations) }\end{array}$ & [143] \\
\hline \multirow{2}{*}{$\begin{array}{c}\text { TCF3-PBX1 } \\
\text { (TCR } V \beta \text { and } L c k \text { promoters } \\
/ I g \mu \text { enhancer) }\end{array}$} & - & - & B-ALL (13\%) and T-ALL (33\%) & \multirow{2}{*}[207]{} \\
\hline & $\mathrm{CD} 3 \varepsilon^{-1-}$ & - & B-ALL (40\%) & \\
\hline \multirow[t]{2}{*}{$\begin{array}{c}\text { TCF3-PBX1 } \\
\text { (Cre-driving TCF3 promoter) }\end{array}$} & - & Partial blockage at pro-B/pre-B stage & $\begin{array}{c}\text { B-ALL (Cd19-Cre, 7\%) } \\
\text { B-ALL (Mb1-Cre, 53\%) } \\
\text { B-ALL (Mx1-Cre, 59\%) } \\
\text { Ptpn11, Kras, Nras, Jak1, Jak3 and Il7r mutations } \\
\text { Cdkn2a deletions }\end{array}$ & \multirow[t]{2}{*}[186]{} \\
\hline & $\mathrm{Pax}^{+/-}$ & - & B-ALL (increased penetrance) & \\
\hline \multirow{2}{*}{$\begin{array}{c}\text { BCR-ABL1 } \\
\text { (Sca1 promoter) }\end{array}$} & - & Pre-leukemic $B C R-A B L 1$ HSPCs & B-ALL (low penetrance) & \multirow[b]{2}{*}[208]{} \\
\hline & $\operatorname{Pax} 5^{+/-}$ & $\begin{array}{c}\text { Pro-B/pre-B cells permissive for B-ALL } \\
\text { development }\end{array}$ & B-ALL (high penetrance, 10 months) & \\
\hline
\end{tabular}




\section{Targeting Cell- and Non-Cell-Autonomous Properties of (Pre-)LSCs}

The search for more targeted therapies remains an important challenge based on an understanding of both cell-autonomous and non-cell-autonomous mechanisms involved in leukemia initiation and propagation. Targeting genes encoding for key players in controlling proliferation and differentiation in leukemia remains a dream and, unfortunately, represents very few examples of success in the clinic so far. In addition, most transcription factors, which exert intrinsic functions on cancer cells, are considered "undruggable" by small molecules or blocking antibodies due to their structural configurations, their proteinprotein or protein-DNA interactions and their cellular localizations $[209,210]$. Despite this, the treatment of acute promyelocytic leukemia (APL) represents a prime example of a drug combination that targets both differentiation blockade and the self-renewal activity of LSCs through the proteasome-dependent degradation of the PML-RAR $\alpha$ fusion protein, as described in the pioneer work from de The and colleagues [211,212]. This strategy underscores the importance of targeting the oncoprotein functions as this allowed for a more than $90 \%$ cure rate and very rare relapses, representing a major success in the field of hematologic malignancies [213]. In addition, this demonstrates the proof of concept that targeted degradation of a driver oncogenic transcription factor, along with its associated self-renewal and stem cell-like functions, is the strategy of choice for the long-term cure of leukemia. In ALL, while deciphering the diversity of the different oncogenic subtypes associated with their altered signaling pathways led to the discovery of new therapeutic opportunities [18,19], a significant proportion of patients still have unsatisfactory outcomes. Thus, the importance of challenging therapeutic approaches and of finding new druggable targets that enhance anti-leukemic efficiency remains a topical issue. In that purpose and as a representative example of targeted therapy, it has been demonstrated that the demethylase activity of UTX is essential for the maintenance of SCL/TAL1-positive T-ALL and not for other oncogenic subtypes [214]. Consistently, pharmacological inhibition of UTX with the H3K27 demethylase inhibitor GSK-J4 selectively targets SCL/TAL1-positive leukemic cells. Based on this targeted epigenetic vulnerability, the authors proposed for the first time a subtype-specific therapy in T-ALL [214].

The current cancer therapies target proliferating and metabolically active cancer cells and efficiently reduce the tumor load. However, frequent relapses indicate the persistence of residual resistant cells that escape treatment likely due to a protective microenvironment that blunt their chemosensitivity [215-219]. Indeed, specific locations within the niche may modify the chemosensitivity of primary leukemic blasts $[58,220]$. In addition, growing evidence supports the notion that leukemic cells can remodel their niche into an abnormal environment that contributes to neoplastic progression at the expense of normal hematopoiesis [221]. Thus, the interactions between leukemic cells with the molecular cues provided by their microenvironment are critical to promote leukemia progression and to design new targeted therapies, as is well documented elsewhere both in T-ALL [222,223] and in B-ALL [224]. Interestingly, non-cell-autonomous mechanisms can control the vulnerability of leukemic cells upon treatment, as exemplified by mitochondria transfer from activated stromal cells to rescue ALL cells from drug-induced oxidative stress [225]. Noncell-autonomous pathways can also be exploited to develop therapeutic opportunities, as recently documented by Van Vlierberghe and colleagues showing that endogenous IL7, a cytokine abundantly secreted by the microenvironment, collaborates with glucocorticoids to reveal the sensitivity of residual leukemic cells upon the PIM inhibitor [226,227]. Together, the impact of extrinsic signals in leukemic cells, especially the molecular crosstalk between (pre-)LSCs and their microenvironment should be considered to develop new therapeutic approaches. Modifying the BM niche represents an innovative therapeutic approach to prevent leukemia re-initiation from residual (pre-)LSCs after complete remission. Thus, there is a need to characterize the adhesion molecules and soluble factors involved in the crosstalk between (pre-)LSCs and BM stromal cells. While the in vivo method stays the gold standard approach to study the molecular interactions between (pre-)LSCs and the BM microenvironment, a 3D organotypic "leukemia on-a-chip" microphysiological 
system has been recently developed. This ex vivo bioengineered strategy recapitulates the heterogeneity of the leukemic BM microenvironment and opens the opportunity to perform a niche-based drug screening assay [228].

As described previously using transgenic T-ALL models, a primary oncogene can introduce cell quiescence, drug resistance and self-renewal to pre-LSCs [132,133], three critical properties that can be controlled by their niches. Thus, the development of new drugs targeting specific non-cell-autonomous mechanisms in (pre-)LSCs could open new therapeutic opportunities for more selective treatments. This notion has recently been exploited through the demonstration that a potent inhibitor of dynamin GTPase activity overcome the chemoresistance of pre-LSCs by inhibiting the transduction of key signaling pathways provided by the microenvironment [229]. Therefore, the reliance of leukemic cells on their niches and on non-cell-autonomous pathways together with the failure of chemotherapy in a significant proportion of patients point to the need for novel drug screening strategies incorporating elements of the microenvironment. This has been challenged by the design of the niche-based screening in multiple myeloma (MM) to identify Food and Drug Administration (FDA)-approved compounds that overcome stroma-induced drug resistance [230]. Precisely, this strategy led to the discovery of a chemical inhibitor specifically targeting microtubule-bound kinesin- 5 in $\mathrm{MM}$ cells and allowing a greater selectivity over normal hematopoietic cells [230]. Obviously, the major limit is to target these (pre-)LSCs in primary patient samples, which are not easily amenable to high-throughput screening (HTS) for drug discovery due to their extreme rarity. Despite this, the critical dependency of primary (pre-)LSCs for their microenvironment has been challenged by the design of miniaturized, niche-based assays for chemical screening strategies using both MLL-AF9-induced AML [231] and SCL-LMO1-induced T-ALL [132] models. The latter led to the identification of the 2-methoxyestradiol, an FDA-approved drug inhibiting both the cell-intrinsic SCL oncoprotein and the stroma-dependent NOTCH1-Myc pathway, together with an absence of toxicity towards normal HSC functions. As previously reported, MYC is indeed essential for NOTCH1 activity in T-ALL [232,233], and inhibiting Myc expression via a BRD4 inhibitor effectively killed leukemia-initiating cells [234,235].

Collectively, recapitulating tissue-like properties of primary (pre-)LSCs represents a promising avenue for developing new cancer therapies. In addition, drug repositioning seems to be a powerful alternative strategy to discover novel biological applications of existing drugs that have a well-established dose regimen with favorable pharmacokinetics and pharmacodynamics properties as well as tolerable side effects [236]. In addition, drug repositioning should significantly reduce the time and the cost of the pre-clinical trial. Therefore, the chemical screen of FDA-approved compounds represents an attractive approach to the discovery of novel biological applications of a known drug and its rapid translation to the clinic.

\section{Conclusions}

The leukemic stem cell concept has important clinical implications and is already applied for patient stratification and for the development of more effective therapies against hematopoietic malignancies. In this review, we presented multiple lines of evidence for the complexity of leukemic cells from ALL patients that include cellular, molecular, genetic and functional heterogeneity. We described the different technological approaches that led to the recognition that leukemic cells evolve towards a nonlinear evolution process during the progression of the disease. Then, we focused on the development of improved methods, particularly the use of transgenic mice, to detect, purify and characterize pre-malignant stem cells before they have acquired additional genetic alterations and propagating properties. We described how a primary oncogenic transcription factor can reprogram stem cell-like functions to normal progenitors, such as self-renewal and cell dormancy, and that led to the emergence of pre-LSCs. Finally, we discussed the biological as well as the clinical importance of studying and targeting the intrinsic and extrinsic properties of pre-LSCs. 
Over the last decade, genome-wide studies greatly improved the classification of ALL patients, enabling the identification of diverse and heterogeneous oncogenic subtypes that led to a better patient stratification, clinical prognosis and treatment orientation. Despite considerable improvements in overall survival, a significant proportion of ALL patients still have unsatisfactory outcomes. Moreover, the finding of therapeutic strategies targeting both the self-renewal and differentiation blockade of leukemic cells in ALL has not yet been achieved. Based on a better understanding of the intratumoral heterogeneity and on the deciphering of both the cell-autonomous and non-cell-autonomous mechanisms driving the emergence of leukemia-initiating cells, we expect in the near future the identification of new druggable targets and therapeutic opportunities that might render ALL a curable disease.

Funding: This research received no external funding.

Conflicts of Interest: The authors declare no conflict of interest.

\section{References}

1. Takahashi, K.; Yamanaka, S. Induction of pluripotent stem cells from mouse embryonic and adult fibroblast cultures by defined factors. Cell 2006, 126, 663-676. [CrossRef] [PubMed]

2. Wuputra, K.; Ku, C.C.; Wu, D.C.; Lin, Y.C.; Saito, S.; Yokoyama, K.K. Prevention of tumor risk associated with the reprogramming of human pluripotent stem cells. J. Exp. Clin. Cancer. Res. 2020, 39, 100. [CrossRef] [PubMed]

3. Bradner, J.E.; Hnisz, D.; Young, R.A. Transcriptional addiction in cancer. Cell 2017, 168, 629-643. [CrossRef] [PubMed]

4. Malta, T.M.; Sokolov, A.; Gentles, A.J.; Burzykowski, T.; Poisson, L.; Weinstein, J.N.; Kaminska, B.; Huelsken, J.; Omberg, L.; Gevaert, O.; et al. Machine learning identifies stemness features associated with oncogenic dedifferentiation. Cell 2018, 173, 338-354. [CrossRef]

5. Swiers, G.; Patient, R.; Loose, M. Genetic regulatory networks programming hematopoietic stem cells and erythroid lineage specification. Dev. Biol. 2006, 294, 525-540. [CrossRef]

6. Sloma, I.; Jiang, X.; Eaves, A.C.; Eaves, C.J. Insights into the stem cells of chronic myeloid leukemia. Leukemia 2010, 24, 1823-1833. [CrossRef]

7. Fialkow, P.J.; Gartler, S.M.; Yoshida, A. Clonal origin of chronic myelocytic leukemia in man. Proc. Natl. Acad. Sci. USA 1967, 58, 1468-1471. [CrossRef]

8. Lapidot, T.; Sirard, C.; Vormoor, J.; Murdoch, B.; Hoang, T.; Caceres-Cortes, J.; Minden, M.; Paterson, B.; Caligiuri, M.A.; Dick, J.E. A cell initiating human acute myeloid leukaemia after transplantation into scid mice. Nature 1994, 367, 645-648. [CrossRef]

9. Bonnet, D.; Dick, J.E. Human acute myeloid leukemia is organized as a hierarchy that originates from a primitive hematopoietic cell. Nat. Med. 1997, 3, 730-737. [CrossRef]

10. Bereshchenko, O.; Mancini, E.; Moore, S.; Bilbao, D.; Mansson, R.; Luc, S.; Grover, A.; Jacobsen, S.E.; Bryder, D.; Nerlov, C. Hematopoietic stem cell expansion precedes the generation of committed myeloid leukemia-initiating cells in c/ebpalpha mutant aml. Cancer Cell 2009, 16, 390-400. [CrossRef]

11. Miyamoto, T.; Weissman, I.L.; Akashi, K. Aml1/eto-expressing nonleukemic stem cells in acute myelogenous leukemia with 8;21 chromosomal translocation. Proc. Natl. Acad. Sci. USA 2000, 97, 7521-7526. [CrossRef]

12. Huntly, B.J.; Shigematsu, H.; Deguchi, K.; Lee, B.H.; Mizuno, S.; Duclos, N.; Rowan, R.; Amaral, S.; Curley, D.; Williams, I.R.; et al. Moz-tif2, but not bcr-abl, confers properties of leukemic stem cells to committed murine hematopoietic progenitors. Cancer Cell 2004, 6, 587-596. [CrossRef]

13. Krivtsov, A.V.; Twomey, D.; Feng, Z.; Stubbs, M.C.; Wang, Y.; Faber, J.; Levine, J.E.; Wang, J.; Hahn, W.C.; Gilliland, D.G.; et al. Transformation from committed progenitor to leukaemia stem cell initiated by mll-af9. Nature 2006, 442, 818-822. [CrossRef]

14. Cozzio, A.; Passegue, E.; Ayton, P.M.; Karsunky, H.; Cleary, M.L.; Weissman, I.L. Similar mll-associated leukemias arising from self-renewing stem cells and short-lived myeloid progenitors. Genes Dev. 2003, 17, 3029-3035. [CrossRef]

15. Guibal, F.C.; Alberich-Jorda, M.; Hirai, H.; Ebralidze, A.; Levantini, E.; Di Ruscio, A.; Zhang, P.; Santana-Lemos, B.A.; Neuberg, D.; Wagers, A.J.; et al. Identification of a myeloid committed progenitor as the cancer-initiating cell in acute promyelocytic leukemia. Blood 2009, 114, 5415-5425. [CrossRef]

16. Wojiski, S.; Guibal, F.C.; Kindler, T.; Lee, B.H.; Jesneck, J.L.; Fabian, A.; Tenen, D.G.; Gilliland, D.G. Pml-raralpha initiates leukemia by conferring properties of self-renewal to committed promyelocytic progenitors. Leukemia 2009, 23, 1462-1471. [CrossRef]

17. Inaba, H.; Pui, C.H. Advances in the diagnosis and treatment of pediatric acute lymphoblastic leukemia. J. Clin. Med. 2021, 10, 1926. [CrossRef]

18. Lato, M.W.; Przysucha, A.; Grosman, S.; Zawitkowska, J.; Lejman, M. The new therapeutic strategies in pediatric t-cell acute lymphoblastic leukemia. Int. J. Mol. Sci. 2021, 22, 4502. [CrossRef]

19. Ratti, S.; Lonetti, A.; Follo, M.Y.; Paganelli, F.; Martelli, A.M.; Chiarini, F.; Evangelisti, C. B-all complexity: Is targeted therapy still a valuable approach for pediatric patients? Cancers 2020, 12, 3498. [CrossRef]

20. Tardif, M.; Souza, A.; Krajinovic, M.; Bittencourt, H.; Tran, T.H. Molecular-based and antibody-based targeted pharmacological approaches in childhood acute lymphoblastic leukemia. Expert Opin. Pharmacother. 2021, 22, 1871-1887. [CrossRef] 
21. Valent, P.; Bonnet, D.; De Maria, R.; Lapidot, T.; Copland, M.; Melo, J.V.; Chomienne, C.; Ishikawa, F.; Schuringa, J.J.; Stassi, G.; et al. Cancer stem cell definitions and terminology: The devil is in the details. Nat. Rev. Cancer 2012, 12, 767-775. [CrossRef]

22. Till, J.E.; Mc, C.E. A direct measurement of the radiation sensitivity of normal mouse bone marrow cells. Radiat. Res. 1961, 14, 213-222. [CrossRef]

23. Spangrude, G.J.; Heimfeld, S.; Weissman, I.L. Purification and characterization of mouse hematopoietic stem cells. Science 1988, 241, 58-62. [CrossRef]

24. Morrison, S.J.; Weissman, I.L. The long-term repopulating subset of hematopoietic stem cells is deterministic and isolatable by phenotype. Immunity 1994, 1, 661-673. [CrossRef]

25. Osawa, M.; Hanada, K.; Hamada, H.; Nakauchi, H. Long-term lymphohematopoietic reconstitution by a single cd34-low/negative hematopoietic stem cell. Science 1996, 273, 242-245. [CrossRef]

26. Berenson, R.J.; Andrews, R.G.; Bensinger, W.I.; Kalamasz, D.; Knitter, G.; Buckner, C.D.; Bernstein, I.D. Antigen cd34+ marrow cells engraft lethally irradiated baboons. J. Clin. Investig. 1988, 81, 951-955. [CrossRef]

27. Bhatia, M.; Wang, J.C.; Kapp, U.; Bonnet, D.; Dick, J.E. Purification of primitive human hematopoietic cells capable of repopulating immune-deficient mice. Proc. Natl. Acad. Sci. USA 1997, 94, 5320-5325. [CrossRef]

28. Kreso, A.; Dick, J.E. Evolution of the cancer stem cell model. Cell Stem Cell 2014, 14, 275-291. [CrossRef]

29. Hope, K.J.; Jin, L.; Dick, J.E. Acute myeloid leukemia originates from a hierarchy of leukemic stem cell classes that differ in self-renewal capacity. Nat. Immunol. 2004, 5, 738-743. [CrossRef]

30. Ishikawa, F.; Yoshida, S.; Saito, Y.; Hijikata, A.; Kitamura, H.; Tanaka, S.; Nakamura, R.; Tanaka, T.; Tomiyama, H.; Saito, N.; et al. Chemotherapy-resistant human aml stem cells home to and engraft within the bone-marrow endosteal region. Nat. Biotechnol. 2007, 25, 1315-1321. [CrossRef]

31. Eppert, K.; Takenaka, K.; Lechman, E.R.; Waldron, L.; Nilsson, B.; van Galen, P.; Metzeler, K.H.; Poeppl, A.; Ling, V.; Beyene, J.; et al. Stem cell gene expression programs influence clinical outcome in human leukemia. Nat. Med. 2011, 17, 1086-1093. [CrossRef] [PubMed]

32. Goardon, N.; Marchi, E.; Atzberger, A.; Quek, L.; Schuh, A.; Soneji, S.; Woll, P.; Mead, A.; Alford, K.A.; Rout, R.; et al. Coexistence of lmpp-like and gmp-like leukemia stem cells in acute myeloid leukemia. Cancer Cell 2011, 19, 138-152. [CrossRef] [PubMed]

33. Sarry, J.E.; Murphy, K.; Perry, R.; Sanchez, P.V.; Secreto, A.; Keefer, C.; Swider, C.R.; Strzelecki, A.C.; Cavelier, C.; Recher, C.; et al. Human acute myelogenous leukemia stem cells are rare and heterogeneous when assayed in nod/scid/il2rgammac-deficient mice. J. Clin. Investig. 2011, 121, 384-395. [CrossRef] [PubMed]

34. Thomas, D.; Majeti, R. Biology and relevance of human acute myeloid leukemia stem cells. Blood 2017, 129, 1577-1585. [CrossRef]

35. Taussig, D.C.; Miraki-Moud, F.; Anjos-Afonso, F.; Pearce, D.J.; Allen, K.; Ridler, C.; Lillington, D.; Oakervee, H.; Cavenagh, J.; Agrawal, S.G.; et al. Anti-cd38 antibody-mediated clearance of human repopulating cells masks the heterogeneity of leukemiainitiating cells. Blood 2008, 112, 568-575. [CrossRef]

36. Greaves, M. Leukaemia 'firsts' in cancer research and treatment. Nat. Rev. Cancer 2016, 16, 163-172. [CrossRef]

37. Lang, F.; Wojcik, B.; Rieger, M.A. Stem cell hierarchy and clonal evolution in acute lymphoblastic leukemia. Stem Cells Int. 2015, 2015, 137164. [CrossRef]

38. Cobaleda, C.; Gutierrez-Cianca, N.; Perez-Losada, J.; Flores, T.; Garcia-Sanz, R.; Gonzalez, M.; Sanchez-Garcia, I. A primitive hematopoietic cell is the target for the leukemic transformation in human philadelphia-positive acute lymphoblastic leukemia. Blood 2000, 95, 1007-1013. [CrossRef]

39. Cox, C.V.; Evely, R.S.; Oakhill, A.; Pamphilon, D.H.; Goulden, N.J.; Blair, A. Characterization of acute lymphoblastic leukemia progenitor cells. Blood 2004, 104, 2919-2925. [CrossRef]

40. Hotfilder, M.; Rottgers, S.; Rosemann, A.; Jurgens, H.; Harbott, J.; Vormoor, J. Immature cd34+cd19- progenitor/stem cells in tel/aml1-positive acute lymphoblastic leukemia are genetically and functionally normal. Blood 2002, 100, 640-646. [CrossRef]

41. Castor, A.; Nilsson, L.; Astrand-Grundstrom, I.; Buitenhuis, M.; Ramirez, C.; Anderson, K.; Strombeck, B.; Garwicz, S.; Bekassy, A.N.; Schmiegelow, K.; et al. Distinct patterns of hematopoietic stem cell involvement in acute lymphoblastic leukemia. Nat. Med. 2005, 11, 630-637. [CrossRef]

42. Kong, Y.; Yoshida, S.; Saito, Y.; Doi, T.; Nagatoshi, Y.; Fukata, M.; Saito, N.; Yang, S.M.; Iwamoto, C.; Okamura, J.; et al. $\mathrm{Cd} 34+\mathrm{cd} 38+\mathrm{cd} 19+$ as well as cd34+cd38-cd19+ cells are leukemia-initiating cells with self-renewal capacity in human b-precursor all. Leukemia 2008, 22, 1207-1213. [CrossRef]

43. Le Viseur, C.; Hotfilder, M.; Bomken, S.; Wilson, K.; Rottgers, S.; Schrauder, A.; Rosemann, A.; Irving, J.; Stam, R.W.; Shultz, L.D.; et al. In childhood acute lymphoblastic leukemia, blasts at different stages of immunophenotypic maturation have stem cell properties. Cancer Cell 2008, 14, 47-58. [CrossRef]

44. Aoki, Y.; Watanabe, T.; Saito, Y.; Kuroki, Y.; Hijikata, A.; Takagi, M.; Tomizawa, D.; Eguchi, M.; Eguchi-Ishimae, M.; Kaneko, A.; et al. Identification of cd34+ and cd34- leukemia-initiating cells in mll-rearranged human acute lymphoblastic leukemia. Blood 2015, 125, 967-980. [CrossRef]

45. Rehe, K.; Wilson, K.; Bomken, S.; Williamson, D.; Irving, J.; den Boer, M.L.; Stanulla, M.; Schrappe, M.; Hall, A.G.; Heidenreich, O; ; et al. Acute b lymphoblastic leukaemia-propagating cells are present at high frequency in diverse lymphoblast populations. EMBO Mol. Med. 2013, 5, 38-51. [CrossRef]

46. Elder, A.; Bomken, S.; Wilson, I.; Blair, H.J.; Cockell, S.; Ponthan, F.; Dormon, K.; Pal, D.; Heidenreich, O.; Vormoor, J. Abundant and equipotent founder cells establish and maintain acute lymphoblastic leukaemia. Leukemia 2017, 31, 2577-2586. [CrossRef] 
47. Lang, F.; Wojcik, B.; Bothur, S.; Knecht, C.; Falkenburg, J.H.; Schroeder, T.; Serve, H.; Ottmann, O.G.; Rieger, M.A. Plastic cd34 and cd38 expression in adult b-cell precursor acute lymphoblastic leukemia explains ambiguity of leukemia-initiating stem cell populations. Leukemia 2017, 31, 731-734. [CrossRef]

48. Orlando, E.J.; Han, X.; Tribouley, C.; Wood, P.A.; Leary, R.J.; Riester, M.; Levine, J.E.; Qayed, M.; Grupp, S.A.; Boyer, M.; et al. Genetic mechanisms of target antigen loss in car19 therapy of acute lymphoblastic leukemia. Nat. Med. 2018, 24, 1504-1506. [CrossRef]

49. Rabilloud, T.; Potier, D.; Pankaew, S.; Nozais, M.; Loosveld, M.; Payet-Bornet, D. Single-cell profiling identifies pre-existing cd19-negative subclones in a b-all patient with cd19-negative relapse after car-t therapy. Nat. Commun. 2021, 12, 865. [CrossRef]

50. Sedek, L.; Theunissen, P.; Sobral da Costa, E.; van der Sluijs-Gelling, A.; Mejstrikova, E.; Gaipa, G.; Sonsala, A.; Twardoch, M.; Oliveira, E.; Novakova, M.; et al. Differential expression of cd73, cd86 and cd304 in normal vs. Leukemic b-cell precursors and their utility as stable minimal residual disease markers in childhood b-cell precursor acute lymphoblastic leukemia. J. Immunol. Methods 2019, 475, 112429. [CrossRef]

51. Tsitsikov, E.; Harris, M.H.; Silverman, L.B.; Sallan, S.E.; Weinberg, O.K. Role of cd81 and cd58 in minimal residual disease detection in pediatric b lymphoblastic leukemia. Int. J. Lab. Hematol. 2018, 40, 343-351. [CrossRef]

52. Armstrong, F.; de la Grange, P.B.; Gerby, B.; Rouyez, M.C.; Calvo, J.; Fontenay, M.; Boissel, N.; Dombret, H.; Baruchel, A.; Landman-Parker, J.; et al. Notch is a key regulator of human t-cell acute leukemia initiating cell activity. Blood 2009, 113, 1730-1740. [CrossRef]

53. Cox, C.V.; Martin, H.M.; Kearns, P.R.; Virgo, P.; Evely, R.S.; Blair, A. Characterization of a progenitor cell population in childhood t-cell acute lymphoblastic leukemia. Blood 2007, 109, 674-682. [CrossRef]

54. Gerby, B.; Clappier, E.; Armstrong, F.; Deswarte, C.; Calvo, J.; Poglio, S.; Soulier, J.; Boissel, N.; Leblanc, T.; Baruchel, A.; et al. Expression of cd34 and cd7 on human t-cell acute lymphoblastic leukemia discriminates functionally heterogeneous cell populations. Leukemia 2011, 25, 1249-1258. [CrossRef]

55. Chiu, P.P.; Jiang, H.; Dick, J.E. Leukemia-initiating cells in human t-lymphoblastic leukemia exhibit glucocorticoid resistance. Blood 2010, 116, 5268-5279. [CrossRef]

56. Ma, W.; Gutierrez, A.; Goff, D.J.; Geron, I.; Sadarangani, A.; Jamieson, C.A.; Court, A.C.; Shih, A.Y.; Jiang, Q.; Wu, C.C.; et al. Notch1 signaling promotes human $\mathrm{t}$-cell acute lymphoblastic leukemia initiating cell regeneration in supportive niches. $P L O S$ ONE 2012, 7, e39725.

57. Poglio, S.; Lewandowski, D.; Calvo, J.; Caye, A.; Gros, A.; Laharanne, E.; Leblanc, T.; Landman-Parker, J.; Baruchel, A.; Soulier, J.; et al. Speed of leukemia development and genetic diversity in xenograft models of $\mathrm{t}$ cell acute lymphoblastic leukemia. Oncotarget 2016, 7, 41599-41611. [CrossRef]

58. Cahu, X.; Calvo, J.; Poglio, S.; Prade, N.; Colsch, B.; Arcangeli, M.-L.; Leblanc, T.; Petit, A.; Baleydier, F.; Baruchel, A.; et al. Bone marrow sites differently imprint dormancy and chemoresistance to T-cell acute lymphoblastic leukemia. Blood Adv. 2017, 1, 1760-1772. [CrossRef]

59. Ebinger, S.; Ozdemir, E.Z.; Ziegenhain, C.; Tiedt, S.; Castro Alves, C.; Grunert, M.; Dworzak, M.; Lutz, C.; Turati, V.A.; Enver, T.; et al. Characterization of rare, dormant, and therapy-resistant cells in acute lymphoblastic leukemia. Cancer Cell 2016, 30, 849-862. [CrossRef]

60. Yan, F.; Wong, N.C.; Powell, D.R.; Curtis, D.J. A 9-gene score for risk stratification in b-cell acute lymphoblastic leukemia. Leukemia 2020, 34, 3070-3074. [CrossRef]

61. Ng, S.W.; Mitchell, A.; Kennedy, J.A.; Chen, W.C.; McLeod, J.; Ibrahimova, N.; Arruda, A.; Popescu, A.; Gupta, V.; Schimmer, A.D.; et al. A 17-gene stemness score for rapid determination of risk in acute leukaemia. Nature 2016, 540, 433-437. [CrossRef] [PubMed]

62. Inaba, H.; Mullighan, C.G. Pediatric acute lymphoblastic leukemia. Haematologica 2020, 105, 2524-2539. [CrossRef] [PubMed]

63. Kimura, S.; Mullighan, C.G. Molecular markers in all: Clinical implications. Best Pract. Res. Clin. Haematol. 2020, $33,101193$. [CrossRef] [PubMed]

64. Alexandrov, L.B.; Nik-Zainal, S.; Wedge, D.C.; Aparicio, S.A.; Behjati, S.; Biankin, A.V.; Bignell, G.R.; Bolli, N.; Borg, A.; Borresen-Dale, A.L.; et al. Signatures of mutational processes in human cancer. Nature 2013, 500, 415-421. [CrossRef] [PubMed]

65. Anderson, K.; Lutz, C.; van Delft, F.W.; Bateman, C.M.; Guo, Y.; Colman, S.M.; Kempski, H.; Moorman, A.V.; Titley, I.; Swansbury, J.; et al. Genetic variegation of clonal architecture and propagating cells in leukaemia. Nature 2011, 469, 356-361. [CrossRef] [PubMed]

66. Mullighan, C.G.; Phillips, L.A.; Su, X.; Ma, J.; Miller, C.B.; Shurtleff, S.A.; Downing, J.R. Genomic analysis of the clonal origins of relapsed acute lymphoblastic leukemia. Science 2008, 322, 1377-1380. [CrossRef]

67. Mullighan, C.G.; Zhang, J.; Kasper, L.H.; Lerach, S.; Payne-Turner, D.; Phillips, L.A.; Heatley, S.L.; Holmfeldt, L.; CollinsUnderwood, J.R.; Ma, J.; et al. Crebbp mutations in relapsed acute lymphoblastic leukaemia. Nature 2011, 471, 235-239. [CrossRef]

68. Yang, J.J.; Bhojwani, D.; Yang, W.; Cai, X.; Stocco, G.; Crews, K.; Wang, J.; Morrison, D.; Devidas, M.; Hunger, S.P.; et al. Genome-wide copy number profiling reveals molecular evolution from diagnosis to relapse in childhood acute lymphoblastic leukemia. Blood 2008, 112, 4178-4183. [CrossRef]

69. Tosello, V.; Mansour, M.R.; Barnes, K.; Paganin, M.; Sulis, M.L.; Jenkinson, S.; Allen, C.G.; Gale, R.E.; Linch, D.C.; Palomero, T.; et al. Wt1 mutations in t-all. Blood 2009, 114, 1038-1045. [CrossRef] 
70. Kuster, L.; Grausenburger, R.; Fuka, G.; Kaindl, U.; Krapf, G.; Inthal, A.; Mann, G.; Kauer, M.; Rainer, J.; Kofler, R.; et al. Etv6/runx1-positive relapses evolve from an ancestral clone and frequently acquire deletions of genes implicated in glucocorticoid signaling. Blood 2011, 117, 2658-2667. [CrossRef]

71. Van Delft, F.W.; Horsley, S.; Colman, S.; Anderson, K.; Bateman, C.; Kempski, H.; Zuna, J.; Eckert, C.; Saha, V.; Kearney, L.; et al. Clonal origins of relapse in etv6-runx1 acute lymphoblastic leukemia. Blood 2011, 117, 6247-6254. [CrossRef]

72. Ribera, J.; Zamora, L.; Morgades, M.; Mallo, M.; Solanes, N.; Batlle, M.; Vives, S.; Granada, I.; Junca, J.; Malinverni, R.; et al. Copy number profiling of adult relapsed b-cell precursor acute lymphoblastic leukemia reveals potential leukemia progression mechanisms. Genes Chromosomes Cancer 2017, 56, 810-820. [CrossRef]

73. Theunissen, P.M.J.; de Bie, M.; van Zessen, D.; de Haas, V.; Stubbs, A.P.; van der Velden, V.H.J. Next-generation antigen receptor sequencing of paired diagnosis and relapse samples of b-cell acute lymphoblastic leukemia: Clonal evolution and implications for minimal residual disease target selection. Leuk. Res. 2019, 76, 98-104. [CrossRef]

74. Forero-Castro, M.; Montano, A.; Robledo, C.; Garcia de Coca, A.; Fuster, J.L.; de Las Heras, N.; Queizan, J.A.; Hernandez-Sanchez, M.; Corchete-Sanchez, L.A.; Martin-Izquierdo, M.; et al. Integrated genomic analysis of chromosomal alterations and mutations in b-cell acute lymphoblastic leukemia reveals distinct genetic profiles at relapse. Diagnostics 2020, 10, 455. [CrossRef]

75. Waanders, E.; Gu, Z.; Dobson, S.M.; Antic, Z.; Crawford, J.C.; Ma, X.; Edmonson, M.N.; Payne-Turner, D.; van der Vorst, M.; Jongmans, M.C.J.; et al. Mutational landscape and patterns of clonal evolution in relapsed pediatric acute lymphoblastic leukemia. Blood Cancer Discov. 2020, 1, 96-111. [CrossRef]

76. Mullighan, C.G. Molecular genetics of b-precursor acute lymphoblastic leukemia. J. Clin. Investig. 2012, 122, 3407-3415. [CrossRef]

77. Ma, X.; Edmonson, M.; Yergeau, D.; Muzny, D.M.; Hampton, O.A.; Rusch, M.; Song, G.; Easton, J.; Harvey, R.C.; Wheeler, D.A.; et al. Rise and fall of subclones from diagnosis to relapse in pediatric b-acute lymphoblastic leukaemia. Nat. Commun. 2015, 6, 6604. [CrossRef]

78. Oshima, K.; Khiabanian, H.; da Silva-Almeida, A.C.; Tzoneva, G.; Abate, F.; Ambesi-Impiombato, A.; Sanchez-Martin, M.; Carpenter, Z.; Penson, A.; Perez-Garcia, A.; et al. Mutational landscape, clonal evolution patterns, and role of ras mutations in relapsed acute lymphoblastic leukemia. Proc. Natl. Acad. Sci. USA 2016, 113, 11306-11311. [CrossRef]

79. Jaiswal, S.; Fontanillas, P.; Flannick, J.; Manning, A.; Grauman, P.V.; Mar, B.G.; Lindsley, R.C.; Mermel, C.H.; Burtt, N.; Chavez, A.; et al. Age-related clonal hematopoiesis associated with adverse outcomes. N. Engl. J. Med. 2014, 371, 2488-2498. [CrossRef]

80. Acuna-Hidalgo, R.; Sengul, H.; Steehouwer, M.; van de Vorst, M.; Vermeulen, S.H.; Kiemeney, L.; Veltman, J.A.; Gilissen, C.; Hoischen, A. Ultra-sensitive sequencing identifies high prevalence of clonal hematopoiesis-associated mutations throughout adult life. Am. J. Hum. Genet. 2017, 101, 50-64. [CrossRef] [PubMed]

81. Bowman, R.L.; Busque, L.; Levine, R.L. Clonal hematopoiesis and evolution to hematopoietic malignancies. Cell Stem Cell 2018, 22, 157-170. [CrossRef] [PubMed]

82. Shlush, L.I.; Zandi, S.; Mitchell, A.; Chen, W.C.; Brandwein, J.M.; Gupta, V.; Kennedy, J.A.; Schimmer, A.D.; Schuh, A.C.; Yee, K.W.; et al. Identification of pre-leukaemic haematopoietic stem cells in acute leukaemia. Nature 2014, 506, 328-333. [CrossRef] [PubMed]

83. Corces-Zimmerman, M.R.; Hong, W.J.; Weissman, I.L.; Medeiros, B.C.; Majeti, R. Preleukemic mutations in human acute myeloid leukemia affect epigenetic regulators and persist in remission. Proc. Natl. Acad. Sci. USA 2014, 111, 2548-2553. [CrossRef]

84. Shlush, L.I.; Mitchell, A.; Heisler, L.; Abelson, S.; Ng, S.W.K.; Trotman-Grant, A.; Medeiros, J.J.F.; Rao-Bhatia, A.; JaciwZurakowsky, I.; Marke, R.; et al. Tracing the origins of relapse in acute myeloid leukaemia to stem cells. Nature 2017, 547, 104-108. [CrossRef]

85. Velten, L.; Story, B.A.; Hernandez-Malmierca, P.; Raffel, S.; Leonce, D.R.; Milbank, J.; Paulsen, M.; Demir, A.; Szu-Tu, C.; Fromel, R.; et al. Identification of leukemic and pre-leukemic stem cells by clonal tracking from single-cell transcriptomics. Nat. Commun. 2021, 12, 1366. [CrossRef]

86. Clappier, E.; Gerby, B.; Sigaux, F.; Delord, M.; Touzri, F.; Hernandez, L.; Ballerini, P.; Baruchel, A.; Pflumio, F.; Soulier, J. Clonal selection in xenografted human $\mathrm{t}$ cell acute lymphoblastic leukemia recapitulates gain of malignancy at relapse. J. Exp. Med. 2011, 208, 653-661. [CrossRef]

87. Notta, F.; Mullighan, C.G.; Wang, J.C.; Poeppl, A.; Doulatov, S.; Phillips, L.A.; Ma, J.; Minden, M.D.; Downing, J.R.; Dick, J.E. Evolution of human bcr-abl1 lymphoblastic leukaemia-initiating cells. Nature 2011, 469, 362-367. [CrossRef]

88. Bardini, M.; Woll, P.S.; Corral, L.; Luc, S.; Wittmann, L.; Ma, Z.; Lo Nigro, L.; Basso, G.; Biondi, A.; Cazzaniga, G.; et al. Clonal variegation and dynamic competition of leukemia-initiating cells in infant acute lymphoblastic leukemia with mll rearrangement. Leukemia 2015, 29, 38-50. [CrossRef]

89. Richter-Pechanska, P.; Kunz, J.B.; Bornhauser, B.; von Knebel Doeberitz, C.; Rausch, T.; Erarslan-Uysal, B.; Assenov, Y.; Frismantas, V.; Marovca, B.; Waszak, S.M.; et al. Pdx models recapitulate the genetic and epigenetic landscape of pediatric $t$-cell leukemia. EMBO Mol. Med. 2018, 10, e9443. [CrossRef]

90. Wang, K.; Sanchez-Martin, M.; Wang, X.; Knapp, K.M.; Koche, R.; Vu, L.; Nahas, M.K.; He, J.; Hadler, M.; Stein, E.M.; et al. Patient-derived xenotransplants can recapitulate the genetic driver landscape of acute leukemias. Leukemia 2017, 31, 151-158. [CrossRef]

91. Dobson, S.M.; Garcia-Prat, L.; Vanner, R.J.; Wintersinger, J.; Waanders, E.; Gu, Z.; McLeod, J.; Gan, O.I.; Grandal, I.; Payne-Turner, D.; et al. Relapse-fated latent diagnosis subclones in acute $b$ lineage leukemia are drug tolerant and possess distinct metabolic programs. Cancer Discov. 2020, 10, 568-587. [CrossRef] [PubMed] 
92. Van Galen, P.; Kreso, A.; Mbong, N.; Kent, D.G.; Fitzmaurice, T.; Chambers, J.E.; Xie, S.; Laurenti, E.; Hermans, K.; Eppert, K.; et al. The unfolded protein response governs integrity of the haematopoietic stem-cell pool during stress. Nature 2014, 510, 268-272. [CrossRef] [PubMed]

93. Van Galen, P.; Mbong, N.; Kreso, A.; Schoof, E.M.; Wagenblast, E.; Ng, S.W.K.; Krivdova, G.; Jin, L.; Nakauchi, H.; Dick, J.E. Integrated stress response activity marks stem cells in normal hematopoiesis and leukemia. Cell Rep. 2018, 25, $1109-1117$. [CrossRef] [PubMed]

94. Spitzer, M.H.; Nolan, G.P. Mass cytometry: Single cells, many features. Cell 2016, 165, 780-791. [CrossRef]

95. Good, Z.; Sarno, J.; Jager, A.; Samusik, N.; Aghaeepour, N.; Simonds, E.F.; White, L.; Lacayo, N.J.; Fantl, W.J.; Fazio, G.; et al. Single-cell developmental classification of b cell precursor acute lymphoblastic leukemia at diagnosis reveals predictors of relapse. Nat. Med. 2018, 24, 474-483. [CrossRef]

96. Bendall, S.C.; Davis, K.L.; Amir, E.-A.D.; Tadmor, M.D.; Simonds, E.F.; Chen, T.J.; Shenfeld, D.K.; Nolan, G.P.; Pe'er, D. Single-cell trajectory detection uncovers progression and regulatory coordination in human b cell development. Cell 2014, 157, 714-725. [CrossRef]

97. Chan, L.N.; Murakami, M.A.; Robinson, M.E.; Caeser, R.; Sadras, T.; Lee, J.; Cosgun, K.N.; Kume, K.; Khairnar, V.; Xiao, G.; et al. Signalling input from divergent pathways subverts b cell transformation. Nature 2020, 583, 845-851. [CrossRef]

98. Albertí-Servera, L.; Demeyer, S.; Govaerts, I.; Swings, T.; de Bie, J.; Gielen, O.; Brociner, M.; Michaux, L.; Maertens, J.; Uyttebroeck, A.; et al. Single-cell DNA amplicon sequencing reveals clonal heterogeneity and evolution in T-cell acute lymphoblastic leukemia. Blood 2021, 137, 801-811. [CrossRef]

99. Greaves, M. A causal mechanism for childhood acute lymphoblastic leukaemia. Nat. Rev. Cancer 2018, 18, 471-484. [CrossRef]

100. Hong, D.; Gupta, R.; Ancliff, P.; Atzberger, A.; Brown, J.; Soneji, S.; Green, J.; Colman, S.; Piacibello, W.; Buckle, V.; et al. Initiating and cancer-propagating cells in tel-aml1-associated childhood leukemia. Science 2008, 319, 336-339. [CrossRef]

101. De Guzman, C.G.; Warren, A.J.; Zhang, Z.; Gartland, L.; Erickson, P.; Drabkin, H.; Hiebert, S.W.; Klug, C.A. Hematopoietic stem cell expansion and distinct myeloid developmental abnormalities in a murine model of the aml1-eto translocation. Mol. Cell. Biol. 2002, 22, 5506-5517. [CrossRef]

102. Chen, W.; Kumar, A.R.; Hudson, W.A.; Li, Q.; Wu, B.; Staggs, R.A.; Lund, E.A.; Sam, T.N.; Kersey, J.H. Malignant transformation initiated by mll-af9: Gene dosage and critical target cells. Cancer Cell 2008, 13, 432-440. [CrossRef]

103. Passegue, E.; Wagner, E.F.; Weissman, I.L. Junb deficiency leads to a myeloproliferative disorder arising from hematopoietic stem cells. Cell 2004, 119, 431-443. [CrossRef]

104. Shimizu, R.; Kuroha, T.; Ohneda, O.; Pan, X.; Ohneda, K.; Takahashi, S.; Philipsen, S.; Yamamoto, M. Leukemogenesis caused by incapacitated gata-1 function. Mol. Cell. Biol. 2004, 24, 10814-10825. [CrossRef]

105. Rodrigues, N.P.; Tipping, A.J.; Wang, Z.; Enver, T. Gata-2 mediated regulation of normal hematopoietic stem/progenitor cell function, myelodysplasia and myeloid leukemia. Int. J. Biochem. Cell. Biol. 2012, 44, 457-460. [CrossRef]

106. Smith, L.J.; Curtis, J.E.; Messner, H.A.; Senn, J.S.; Furthmayr, H.; McCulloch, E.A. Lineage infidelity in acute leukemia. Blood 1983, 61, 1138-1145. [CrossRef]

107. Alexander, T.B.; Gu, Z.; Iacobucci, I.; Dickerson, K.; Choi, J.K.; Xu, B.; Payne-Turner, D.; Yoshihara, H.; Loh, M.L.; Horan, J.; et al. The genetic basis and cell of origin of mixed phenotype acute leukaemia. Nature 2018, 562, 373-379. [CrossRef]

108. Peaudecerf, L.; Krenn, G.; Goncalves, P.; Vasseur, F.; Rocha, B. Thymocytes self-renewal: A major hope or a major threat? Immunol. Rev. 2016, 271, 173-184. [CrossRef]

109. Han, J.; Zuniga-Pflucker, J.C. A 2020 view of thymus stromal cells in t cell development. J. Immunol. 2021, 206, 249-256. [CrossRef]

110. Tremblay, C.S.; Hoang, T.; Hoang, T. Early t cell differentiation lessons from t-cell acute lymphoblastic leukemia. Prog. Mol. Biol. Transl. Sci. 2010, 92, 121-156.

111. McCormack, M.P.; Young, L.F.; Vasudevan, S.; de Graaf, C.A.; Codrington, R.; Rabbitts, T.H.; Jane, S.M.; Curtis, D.J. The lmo2 oncogene initiates leukemia in mice by inducing thymocyte self-renewal. Science 2010, 327, 879-883. [CrossRef]

112. Wilson, N.K.; Foster, S.D.; Wang, X.; Knezevic, K.; Schutte, J.; Kaimakis, P.; Chilarska, P.M.; Kinston, S.; Ouwehand, W.H.; Dzierzak, E.; et al. Combinatorial transcriptional control in blood stem/progenitor cells: Genome-wide analysis of ten major transcriptional regulators. Cell Stem Cell 2010, 7, 532-544. [CrossRef]

113. Herblot, S.; Steff, A.M.; Hugo, P.; Aplan, P.D.; Hoang, T. Scl and lmo1 alter thymocyte differentiation: Inhibition of e2a-heb function and pre-t alpha chain expression. Nat. Immunol. 2000, 1, 138-144. [CrossRef]

114. Gerby, B.; Tremblay, C.S.; Tremblay, M.; Rojas-Sutterlin, S.; Herblot, S.; Hebert, J.; Sauvageau, G.; Lemieux, S.; Lecuyer, E.; Veiga, D.F.; et al. Scl, lmo1 and notch1 reprogram thymocytes into self-renewing cells. PLoS Genet. 2014, 10, e1004768. [CrossRef]

115. Goossens, S.; van Vlierberghe, P. Controlling pre-leukemic thymocyte self-renewal. PLoS Genet. 2014, 10, e1004881. [CrossRef] [PubMed]

116. Curtis, D.J.; Hall, M.A.; van Stekelenburg, L.J.; Robb, L.; Jane, S.M.; Begley, C.G. Scl is required for normal function of short-term repopulating hematopoietic stem cells. Blood 2004, 103, 3342-3348. [CrossRef]

117. Reynaud, D.; Ravet, E.; Titeux, M.; Mazurier, F.; Renia, L.; Dubart-Kupperschmitt, A.; Romeo, P.H.; Pflumio, F. Scl/tal1 expression level regulates human hematopoietic stem cell self-renewal and engraftment. Blood 2005, 106, 2318-2328. [CrossRef]

118. Lacombe, J.; Herblot, S.; Rojas-Sutterlin, S.; Haman, A.; Barakat, S.; Iscove, N.N.; Sauvageau, G.; Hoang, T. Scl regulates the quiescence and the long-term competence of hematopoietic stem cells. Blood 2010, 115, 792-803. [CrossRef] [PubMed] 
119. Souroullas, G.P.; Salmon, J.M.; Sablitzky, F.; Curtis, D.J.; Goodell, M.A. Adult hematopoietic stem and progenitor cells require either lyl1 or scl for survival. Cell Stem Cell 2009, 4, 180-186. [CrossRef] [PubMed]

120. McCormack, M.P.; Shields, B.J.; Jackson, J.T.; Nasa, C.; Shi, W.; Slater, N.J.; Tremblay, C.S.; Rabbitts, T.H.; Curtis, D.J. Requirement for lyl1 in a model of lmo2-driven early t-cell precursor all. Blood 2013, 122, 2093-2103. [CrossRef] [PubMed]

121. Tremblay, M.; Tremblay, C.S.; Herblot, S.; Aplan, P.D.; Hebert, J.; Perreault, C.; Hoang, T. Modeling t-cell acute lymphoblastic leukemia induced by the scl and lmo1 oncogenes. Genes Dev. 2010, 24, 1093-1105. [CrossRef]

122. Shi, J.; Fallahi, M.; Luo, J.L.; Petrie, H.T. Nonoverlapping functions for notch1 and notch3 during murine steady-state thymic lymphopoiesis. Blood 2011, 118, 2511-2519. [CrossRef]

123. Radtke, F.; Wilson, A.; Mancini, S.J.; MacDonald, H.R. Notch regulation of lymphocyte development and function. Nat. Immunol. 2004, 5, 247-253. [CrossRef]

124. Mancini, S.J.; Mantei, N.; Dumortier, A.; Suter, U.; MacDonald, H.R.; Radtke, F. Jagged1-dependent notch signaling is dispensable for hematopoietic stem cell self-renewal and differentiation. Blood 2005, 105, 2340-2342. [CrossRef]

125. Maillard, I.; Koch, U.; Dumortier, A.; Shestova, O.; Xu, L.; Sai, H.; Pross, S.E.; Aster, J.C.; Bhandoola, A.; Radtke, F.; et al. Canonical notch signaling is dispensable for the maintenance of adult hematopoietic stem cells. Cell Stem Cell 2008, 2, 356-366. [CrossRef]

126. Chiang, M.Y.; Shestova, O.; Xu, L.; Aster, J.C.; Pear, W.S. Divergent effects of supraphysiological notch signals on leukemia stem cells and hematopoietic stem cells. Blood 2012, 121, 905-917. [CrossRef]

127. Karanu, F.N.; Murdoch, B.; Gallacher, L.; Wu, D.M.; Koremoto, M.; Sakano, S.; Bhatia, M. The notch ligand jagged-1 represents a novel growth factor of human hematopoietic stem cells. J. Exp. Med. 2000, 192, 1365-1372. [CrossRef]

128. Varnum-Finney, B.; Xu, L.; Brashem-Stein, C.; Nourigat, C.; Flowers, D.; Bakkour, S.; Pear, W.S.; Bernstein, I.D. Pluripotent, cytokine-dependent, hematopoietic stem cells are immortalized by constitutive notch1 signaling. Nat. Med. 2000, 6, $1278-1281$. [CrossRef]

129. Weng, A.P.; Ferrando, A.A.; Lee, W.; Morris, J.P.t.; Silverman, L.B.; Sanchez-Irizarry, C.; Blacklow, S.C.; Look, A.T.; Aster, J.C. Activating mutations of notch1 in human $t$ cell acute lymphoblastic leukemia. Science 2004, 306, 269-271. [CrossRef]

130. O’Neil, J.; Calvo, J.; McKenna, K.; Krishnamoorthy, V.; Aster, J.C.; Bassing, C.H.; Alt, F.W.; Kelliher, M.; Look, A.T. Activating notch1 mutations in mouse models of t-all. Blood 2006, 107, 781-785. [CrossRef]

131. Tatarek, J.; Cullion, K.; Ashworth, T.; Gerstein, R.; Aster, J.C.; Kelliher, M.A. Notch1 inhibition targets the leukemia-initiating cells in a tal1/lmo2 mouse model of $\mathrm{t}$-all. Blood 2011, 118, 1579-1590. [CrossRef] [PubMed]

132. Gerby, B.; Veiga, D.F.; Krosl, J.; Nourreddine, S.; Ouellette, J.; Haman, A.; Lavoie, G.; Fares, I.; Tremblay, M.; Litalien, V.; et al. High-throughput screening in niche-based assay identifies compounds to target preleukemic stem cells. J. Clin. Investig. 2016, 126, 4569-4584. [CrossRef] [PubMed]

133. Tremblay, C.S.; Saw, J.; Chiu, S.K.; Wong, N.C.; Tsyganov, K.; Ghotb, S.; Graham, A.N.; Yan, F.; Guirguis, A.A.; Sonderegger, S.E.; et al. Restricted cell cycle is essential for clonal evolution and therapeutic resistance of pre-leukemic stem cells. Nat. Commun. 2018, 9, 3535. [CrossRef] [PubMed]

134. Barnes, D.J.; Melo, J.V. Primitive, quiescent and difficult to kill: The role of non-proliferating stem cells in chronic myeloid leukemia. Cell Cycle 2006, 5, 2862-2866. [CrossRef]

135. Prost, S.; Relouzat, F.; Spentchian, M.; Ouzegdouh, Y.; Saliba, J.; Massonnet, G.; Beressi, J.P.; Verhoeyen, E.; Raggueneau, V.; Maneglier, B.; et al. Erosion of the chronic myeloid leukaemia stem cell pool by ppargamma agonists. Nature 2015, 525, 380-383. [CrossRef]

136. Foudi, A.; Hochedlinger, K.; van Buren, D.; Schindler, J.W.; Jaenisch, R.; Carey, V.; Hock, H. Analysis of histone 2b-gfp retention reveals slowly cycling hematopoietic stem cells. Nat. Biotechnol. 2009, 27, 84-90. [CrossRef]

137. Wilson, A.; Laurenti, E.; Oser, G.; van der Wath, R.C.; Blanco-Bose, W.; Jaworski, M.; Offner, S.; Dunant, C.F.; Eshkind, L.; Bockamp, E.; et al. Hematopoietic stem cells reversibly switch from dormancy to self-renewal during homeostasis and repair. Cell 2008, 135, 1118-1129. [CrossRef]

138. Shields, B.J.; Slape, C.I.; Vo, N.; Jackson, J.T.; Pliego-Zamora, A.; Ranasinghe, H.; Shi, W.; Curtis, D.J.; McCormack, M.P. The nup98-hoxd13 fusion oncogene induces thymocyte self-renewal via lmo2/lyl1. Leukemia 2019, 33, 1868-1880. [CrossRef]

139. Tardif, M.; Gerby, B.; Hoang, T. NUP98-PHF23 and NUP98-HOXD13 oncogenes confer aberrant self-renewal potential to thymocyte progenitors. Exp. Hematol. 2014, 42, S62. [CrossRef]

140. Batta, K.; Florkowska, M.; Kouskoff, V.; Lacaud, G. Direct reprogramming of murine fibroblasts to hematopoietic progenitor cells. Cell Rep. 2014, 9, 1871-1884. [CrossRef]

141. Garcia-Ramirez, I.; Bhatia, S.; Rodriguez-Hernandez, G.; Gonzalez-Herrero, I.; Walter, C.; Gonzalez de Tena-Davila, S.; Parvin, S.; Haas, O.; Woessmann, W.; Stanulla, M.; et al. Lmo2 expression defines tumor cell identity during t-cell leukemogenesis. EMBO J. 2018, 37, e98783. [CrossRef]

142. Abdulla, H.; Vo, A.; Shields, B.J.; Davies, T.J.; Jackson, J.T.; Alserihi, R.; Viney, E.M.; Wong, T.; Yan, F.; Wong, N.C.; et al. T-all can evolve to oncogene independence. Leukemia 2021, 35, 2205-2219. [CrossRef]

143. Rodriguez-Hernandez, G.; Casado-Garcia, A.; Isidro-Hernandez, M.; Picard, D.; Raboso-Gallego, J.; Aleman-Arteaga, S.; Orfao, A.; Blanco, O.; Riesco, S.; Prieto-Matos, P.; et al. The second oncogenic hit determines the cell fate of etv6-runx1 positive leukemia. Front. Cell Dev. Biol. 2021, 9, 704591. [CrossRef]

144. Hardy, R.R.; Li, Y.S.; Allman, D.; Asano, M.; Gui, M.; Hayakawa, K. B-cell commitment, development and selection. Immunol. Rev. 2000, 175, 23-32. [CrossRef] 
145. Melchers, F. The pre-b-cell receptor: Selector of fitting immunoglobulin heavy chains for the b-cell repertoire. Nat. Rev. Immunol. 2005, 5, 578-584. [CrossRef]

146. Meffre, E.; Casellas, R.; Nussenzweig, M.C. Antibody regulation of b cell development. Nat. Immunol. 2000, 1, 379-385. [CrossRef]

147. Nutt, S.L.; Heavey, B.; Rolink, A.G.; Busslinger, M. Commitment to the b-lymphoid lineage depends on the transcription factor pax5. Nature 1999, 401, 556-562. [CrossRef]

148. Cresson, C.; Peron, S.; Jamrog, L.; Rouquie, N.; Prade, N.; Dubois, M.; Hebrard, S.; Lagarde, S.; Gerby, B.; Mancini, S.J.C.; et al. Pax5a and pax5b isoforms are both efficient to drive b cell differentiation. Oncotarget 2018, 9, 32841-32854. [CrossRef]

149. Busslinger, M. Transcriptional control of early b cell development. Annu. Rev. Immunol. 2004, 22, 55-79. [CrossRef]

150. Souabni, A.; Cobaleda, C.; Schebesta, M.; Busslinger, M. Pax5 promotes b lymphopoiesis and blocks t cell development by repressing notch1. Immunity 2002, 17, 781-793. [CrossRef]

151. Nera, K.P.; Kohonen, P.; Narvi, E.; Peippo, A.; Mustonen, L.; Terho, P.; Koskela, K.; Buerstedde, J.M.; Lassila, O. Loss of pax5 promotes plasma cell differentiation. Immunity 2006, 24, 283-293. [CrossRef]

152. Urbanek, P.; Wang, Z.Q.; Fetka, I.; Wagner, E.F.; Busslinger, M. Complete block of early b cell differentiation and altered patterning of the posterior midbrain in mice lacking pax5/bsap. Cell 1994, 79, 901-912. [CrossRef]

153. Rolink, A.G.; Nutt, S.L.; Melchers, F.; Busslinger, M. Long-term in vivo reconstitution of t-cell development by pax5-deficient b-cell progenitors. Nature 1999, 401, 603-606. [CrossRef]

154. Schaniel, C.; Bruno, L.; Melchers, F.; Rolink, A.G. Multiple hematopoietic cell lineages develop in vivo from transplanted pax5-deficient pre-b i-cell clones. Blood 2002, 99, 472-478. [CrossRef]

155. Hoflinger, S.; Kesavan, K.; Fuxa, M.; Hutter, C.; Heavey, B.; Radtke, F.; Busslinger, M. Analysis of notch1 function by in vitro $t$ cell differentiation of pax5 mutant lymphoid progenitors. J. Immunol. 2004, 173, 3935-3944. [CrossRef]

156. Delogu, A.; Schebesta, A.; Sun, Q.; Aschenbrenner, K.; Perlot, T.; Busslinger, M. Gene repression by pax 5 in b cells is essential for blood cell homeostasis and is reversed in plasma cells. Immunity 2006, 24, 269-281. [CrossRef]

157. Schebesta, A.; McManus, S.; Salvagiotto, G.; Delogu, A.; Busslinger, G.A.; Busslinger, M. Transcription factor pax5 activates the chromatin of key genes involved in b cell signaling, adhesion, migration, and immune function. Immunity 2007, $27,49-63$. [CrossRef]

158. Revilla, I.D.R.; Bilic, I.; Vilagos, B.; Tagoh, H.; Ebert, A.; Tamir, I.M.; Smeenk, L.; Trupke, J.; Sommer, A.; Jaritz, M.; et al. The b-cell identity factor pax5 regulates distinct transcriptional programmes in early and late b lymphopoiesis. EMBO J. 2012, 31, 3130-3146. [CrossRef]

159. Cobaleda, C.; Jochum, W.; Busslinger, M. Conversion of mature b cells into $t$ cells by dedifferentiation to uncommitted progenitors. Nature 2007, 449, 473-477. [CrossRef] [PubMed]

160. Nebral, K.; Denk, D.; Attarbaschi, A.; Konig, M.; Mann, G.; Haas, O.A.; Strehl, S. Incidence and diversity of pax5 fusion genes in childhood acute lymphoblastic leukemia. Leukemia 2009, 23, 134-143. [CrossRef] [PubMed]

161. Familiades, J.; Bousquet, M.; Lafage-Pochitaloff, M.; Bene, M.C.; Beldjord, K.; De Vos, J.; Dastugue, N.; Coyaud, E.; Struski, S.; Quelen, C.; et al. Pax5 mutations occur frequently in adult b-cell progenitor acute lymphoblastic leukemia and pax5 haploinsufficiency is associated with bcr-abl1 and tcf3-pbx1 fusion genes: A graall study. Leukemia 2009, 23, 1989-1998. [CrossRef]

162. Mullighan, C.G.; Goorha, S.; Radtke, I.; Miller, C.B.; Coustan-Smith, E.; Dalton, J.D.; Girtman, K.; Mathew, S.; Ma, J.; Pounds, S.B.; et al. Genome-wide analysis of genetic alterations in acute lymphoblastic leukaemia. Nature 2007, 446, 758-764. [CrossRef] [PubMed]

163. Cobaleda, C.; Schebesta, A.; Delogu, A.; Busslinger, M. Pax5: The guardian of b cell identity and function. Nat. Immunol. 2007, 8, 463-470. [CrossRef]

164. Dang, J.; Wei, L.; de Ridder, J.; Su, X.; Rust, A.G.; Roberts, K.G.; Payne-Turner, D.; Cheng, J.; Ma, J.; Qu, C.; et al. Pax5 is a tumor suppressor in mouse mutagenesis models of acute lymphoblastic leukemia. Blood 2015, 125, 3609-3617. [CrossRef]

165. Ramamoorthy, S.; Kometani, K.; Herman, J.S.; Bayer, M.; Boller, S.; Edwards-Hicks, J.; Ramachandran, H.; Li, R.; Klein-Geltink, R.; Pearce, E.L.; et al. Ebf1 and pax5 safeguard leukemic transformation by limiting il-7 signaling, myc expression, and folate metabolism. Genes Dev. 2020, 34, 1503-1519. [CrossRef]

166. Prasad, M.A.; Ungerback, J.; Ahsberg, J.; Somasundaram, R.; Strid, T.; Larsson, M.; Mansson, R.; De Paepe, A.; Lilljebjorn, H.; Fioretos, T.; et al. Ebf1 heterozygosity results in increased DNA damage in pro-b cells and their synergistic transformation by pax5 haploinsufficiency. Blood 2015, 125, 4052-4059. [CrossRef]

167. Chan, L.N.; Chen, Z.; Braas, D.; Lee, J.W.; Xiao, G.; Geng, H.; Cosgun, K.N.; Hurtz, C.; Shojaee, S.; Cazzaniga, V.; et al. Metabolic gatekeeper function of b-lymphoid transcription factors. Nature 2017, 542, 479-483. [CrossRef]

168. Heltemes-Harris, L.M.; Willette, M.J.; Ramsey, L.B.; Qiu, Y.H.; Neeley, E.S.; Zhang, N.; Thomas, D.A.; Koeuth, T.; Baechler, E.C.; Kornblau, S.M.; et al. Ebf1 or pax5 haploinsufficiency synergizes with stat5 activation to initiate acute lymphoblastic leukemia. J. Exp. Med. 2011, 208, 1135-1149. [CrossRef]

169. Roberts, K.G.; Mullighan, C.G. The biology of b-progenitor acute lymphoblastic leukemia. Cold Spring Harb. Perspect. Med. 2020, 10, a034835. [CrossRef]

170. Somasundaram, R.; Prasad, M.A.; Ungerback, J.; Sigvardsson, M. Transcription factor networks in b-cell differentiation link development to acute lymphoid leukemia. Blood 2015, 126, 144-152. [CrossRef]

171. Ungerback, J.; Ahsberg, J.; Strid, T.; Somasundaram, R.; Sigvardsson, M. Combined heterozygous loss of ebf1 and pax5 allows for $\mathrm{t}$-lineage conversion of $\mathrm{b}$ cell progenitors. J. Exp. Med. 2015, 212, 1109-1123. [CrossRef] [PubMed] 
172. Hu, Y.; Zhang, Z.; Kashiwagi, M.; Yoshida, T.; Joshi, I.; Jena, N.; Somasundaram, R.; Emmanuel, A.O.; Sigvardsson, M.; Fitamant, J.; et al. Superenhancer reprogramming drives a b-cell-epithelial transition and high-risk leukemia. Genes Dev. 2016, 30, 1971-1990. [CrossRef]

173. Rodriguez-Hernandez, G.; Opitz, F.V.; Delgado, P.; Walter, C.; Alvarez-Prado, A.F.; Gonzalez-Herrero, I.; Auer, F.; Fischer, U.; Janssen, S.; Bartenhagen, C.; et al. Infectious stimuli promote malignant b-cell acute lymphoblastic leukemia in the absence of aid. Nat. Commun. 2019, 10, 5563. [CrossRef] [PubMed]

174. Martin-Lorenzo, A.; Hauer, J.; Vicente-Duenas, C.; Auer, F.; Gonzalez-Herrero, I.; Garcia-Ramirez, I.; Ginzel, S.; Thiele, R.; Constantinescu, S.N.; Bartenhagen, C.; et al. Infection exposure is a causal factor in b-cell precursor acute lymphoblastic leukemia as a result of pax5-inherited susceptibility. Cancer Discov. 2015, 5, 1328-1343. [CrossRef]

175. Vicente-Duenas, C.; Janssen, S.; Oldenburg, M.; Auer, F.; Gonzalez-Herrero, I.; Casado-Garcia, A.; Isidro-Hernandez, M.; RabosoGallego, J.; Westhoff, P.; Pandyra, A.A.; et al. An intact gut microbiome protects genetically predisposed mice against leukemia. Blood 2020, 136, 2003-2017. [CrossRef]

176. Isidro-Hernandez, M.; Mayado, A.; Casado-Garcia, A.; Martinez-Cano, J.; Palmi, C.; Fazio, G.; Orfao, A.; Ribera, J.; Ribera, J.M.; Zamora, L.; et al. Inhibition of inflammatory signaling in pax5 mutant cells mitigates b-cell leukemogenesis. Sci. Rep. 2020, 10, 19189. [CrossRef]

177. Cobaleda, C.; Vicente-Duenas, C.; Sanchez-Garcia, I. Infectious triggers and novel therapeutic opportunities in childhood b cell leukaemia. Nat. Rev. Immunol. 2021, 21, 570-581. [CrossRef]

178. Medvedovic, J.; Ebert, A.; Tagoh, H.; Busslinger, M. Pax5: A master regulator of b cell development and leukemogenesis. Adv. Immunol. 2011, 111, 179-206.

179. Bousquet, M.; Broccardo, C.; Quelen, C.; Meggetto, F.; Kuhlein, E.; Delsol, G.; Dastugue, N.; Brousset, P. A novel pax5-eln fusion protein identified in b-cell acute lymphoblastic leukemia acts as a dominant negative on wild-type pax5. Blood 2007, 109, 3417-3423. [CrossRef]

180. Coyaud, E.; Struski, S.; Prade, N.; Familiades, J.; Eichner, R.; Quelen, C.; Bousquet, M.; Mugneret, F.; Talmant, P.; Pages, M.P.; et al. Wide diversity of pax5 alterations in b-all: A groupe francophone de cytogenetique hematologique study. Blood 2010, 115, 3089-3097. [CrossRef]

181. Marincevic-Zuniga, Y.; Zachariadis, V.; Cavelier, L.; Castor, A.; Barbany, G.; Forestier, E.; Fogelstrand, L.; Heyman, M.; Abrahamsson, J.; Lönnerholm, G.; et al. PAX5-ESRRB is a recurrent fusion gene in B-cell precursor pediatric acute lymphoblastic leukemia. Haematologica 2015, 101, e20-e23. [CrossRef] [PubMed]

182. Cazzaniga, G.; Daniotti, M.; Tosi, S.; Giudici, G.; Aloisi, A.; Pogliani, E.; Kearney, L.; Biondi, A. The paired box domain gene pax5 is fused to etv6/tel in an acute lymphoblastic leukemia case. Cancer Res. 2001, 61, 4666-4670. [PubMed]

183. Smeenk, L.; Fischer, M.; Jurado, S.; Jaritz, M.; Azaryan, A.; Werner, B.; Roth, M.; Zuber, J.; Stanulla, M.; den Boer, M.L.; et al. Molecular role of the pax5-etv6 oncoprotein in promoting b-cell acute lymphoblastic leukemia. EMBO J. 2017, 36, 718-735. [CrossRef] [PubMed]

184. Jamrog, L.; Chemin, G.; Fregona, V.; Coster, L.; Pasquet, M.; Oudinet, C.; Rouquie, N.; Prade, N.; Lagarde, S.; Cresson, C.; et al. Pax5-eln oncoprotein promotes multistep b-cell acute lymphoblastic leukemia in mice. Proc. Natl. Acad. Sci. USA 2018, 115, 10357-10362. [CrossRef]

185. Van der Weyden, L.; Giotopoulos, G.; Wong, K.; Rust, A.G.; Robles-Espinoza, C.D.; Osaki, H.; Huntly, B.J.; Adams, D.J. Somatic drivers of b-all in a model of etv6-runx1; pax5(+/-) leukemia. BMC Cancer 2015, 15, 585. [CrossRef]

186. Duque-Afonso, J.; Feng, J.; Scherer, F.; Lin, C.H.; Wong, S.H.; Wang, Z.; Iwasaki, M.; Cleary, M.L. Comparative genomics reveals multistep pathogenesis of e2a-pbx1 acute lymphoblastic leukemia. J. Clin. Investig. 2015, 125, 3667-3680. [CrossRef]

187. Shah, S.; Schrader, K.A.; Waanders, E.; Timms, A.E.; Vijai, J.; Miething, C.; Wechsler, J.; Yang, J.; Hayes, J.; Klein, R.J.; et al. A recurrent germline pax 5 mutation confers susceptibility to pre-b cell acute lymphoblastic leukemia. Nat. Genet. 2013, 45, 1226-1231. [CrossRef]

188. Duployez, N.; Jamrog, L.A.; Fregona, V.; Hamelle, C.; Fenwarth, L.; Lejeune, S.; Helevaut, N.; Geffroy, S.; Caillault, A.; MarceauRenaut, A.; et al. Germline pax5 mutation predisposes to familial b-cell precursor acute lymphoblastic leukemia. Blood 2021, 137, 1424-1428. [CrossRef]

189. An, Q.; Wright, S.L.; Konn, Z.J.; Matheson, E.; Minto, L.; Moorman, A.V.; Parker, H.; Griffiths, M.; Ross, F.M.; Davies, T.; et al. Variable breakpoints target pax 5 in patients with dicentric chromosomes: A model for the basis of unbalanced translocations in cancer. Proc. Natl. Acad. Sci. USA 2008, 105, 17050-17054. [CrossRef]

190. Gu, Z.; Churchman, M.L.; Roberts, K.G.; Moore, I.; Zhou, X.; Nakitandwe, J.; Hagiwara, K.; Pelletier, S.; Gingras, S.; Berns, H.; et al. Pax5-driven subtypes of b-progenitor acute lymphoblastic leukemia. Nat. Genet. 2019, 51, 296-307. [CrossRef]

191. Passet, M.; Boissel, N.; Sigaux, F.; Saillard, C.; Bargetzi, M.; Ba, I.; Thomas, X.; Graux, C.; Chalandon, Y.; Leguay, T.; et al. Pax5 p80r mutation identifies a novel subtype of b-cell precursor acute lymphoblastic leukemia with favorable outcome. Blood 2019, 133, 280-284. [CrossRef]

192. Li, J.F.; Dai, Y.T.; Lilljebjorn, H.; Shen, S.H.; Cui, B.W.; Bai, L.; Liu, Y.F.; Qian, M.X.; Kubota, Y.; Kiyoi, H.; et al. Transcriptional landscape of $\mathrm{b}$ cell precursor acute lymphoblastic leukemia based on an international study of 1,223 cases. Proc. Natl. Acad. Sci. USA 2018, 115, E11711-E11720. [CrossRef] 
193. Bastian, L.; Schroeder, M.P.; Eckert, C.; Schlee, C.; Tanchez, J.O.; Kampf, S.; Wagner, D.L.; Schulze, V.; Isaakidis, K.; Lazaro-Navarro, J.; et al. Pax 5 biallelic genomic alterations define a novel subgroup of b-cell precursor acute lymphoblastic leukemia. Leukemia 2019, 33, 1895-1909. [CrossRef]

194. Aplan, P.D.; Jones, C.A.; Chervinsky, D.S.; Zhao, X.; Ellsworth, M.; Wu, C.; McGuire, E.A.; Gross, K.W. An scl gene product lacking the transactivation domain induces bony abnormalities and cooperates with $1 \mathrm{mo} 1$ to generate $\mathrm{t}$-cell malignancies in transgenic mice. EMBO J. 1997, 16, 2408-2419. [CrossRef]

195. Curtis, D.J.; Robb, L.; Strasser, A.; Begley, C.G. The cd2-scl transgene alters the phenotype and frequency of t-lymphomas in n-ras transgenic or p53 deficient mice. Oncogene 1997, 15, 2975-2983. [CrossRef]

196. Goardon, N.; Schuh, A.; Hajar, I.; Ma, X.; Jouault, H.; Dzierzak, E.; Romeo, P.H.; Maouche-Chretien, L. Ectopic expression of tal-1 protein in ly-6e.1-htal-1 transgenic mice induces defects in b- and t-lymphoid differentiation. Blood 2002, 100, 491-500. [CrossRef]

197. Condorelli, G.L.; Facchiano, F.; Valtieri, M.; Proietti, E.; Vitelli, L.; Lulli, V.; Huebner, K.; Peschle, C.; Croce, C.M. T-cell-directed tal-1 expression induces t-cell malignancies in transgenic mice. Cancer Res. 1996, 56, 5113-5119.

198. Kelliher, M.A.; Seldin, D.C.; Leder, P. Tal-1 induces t cell acute lymphoblastic leukemia accelerated by casein kinase iialpha. EMBO J. 1996, 15, 5160-5166. [CrossRef]

199. Draheim, K.M.; Hermance, N.; Yang, Y.; Arous, E.; Calvo, J.; Kelliher, M.A. A DNA-binding mutant of tal1 cooperates with lmo2 to cause t cell leukemia in mice. Oncogene 2011, 30, 1252-1260. [CrossRef]

200. Tremblay, C.S.; Brown, F.C.; Collett, M.; Saw, J.; Chiu, S.K.; Sonderegger, S.E.; Lucas, S.E.; Alserihi, R.; Chau, N.; Toribio, M.L.; et al. Loss-of-function mutations of dynamin 2 promote t-all by enhancing il-7 signalling. Leukemia 2016, 30, 1993-2001. [CrossRef]

201. Shields, B.J.; Alserihi, R.; Nasa, C.; Bogue, C.; Alexander, W.S.; McCormack, M.P. Hhex regulates kit to promote radioresistance of self-renewing thymocytes in lmo2-transgenic mice. Leukemia 2015, 29, 927-938. [CrossRef]

202. Choi, C.W.; Chung, Y.J.; Slape, C.; Aplan, P.D. A nup98-hoxd13 fusion gene impairs differentiation of $b$ and $t$ lymphocytes and leads to expansion of thymocytes with partial tcrb gene rearrangement. J. Immunol. 2009, 183, 6227-6235. [CrossRef]

203. Nutt, S.L.; Vambrie, S.; Steinlein, P.; Kozmik, Z.; Rolink, A.; Weith, A.; Busslinger, M. Independent regulation of the two pax5 alleles during b-cell development. Nat. Genet. 1999, 21, 390-395. [CrossRef]

204. Heltemes-Harris, L.M.; Hubbard, G.K.; La Rue, R.S.; Munro, S.A.; Knudson, T.P.; Yang, R.; Henzler, C.M.; Starr, T.K.; Sarver, A.L.; Kornblau, M.S.; et al. Identification of mutations that cooperate with defects in B cell transcription factors to initiate leukemia. bioRxiv 2020. [CrossRef]

205. Boast, B.; Helian, K.; Andrews, T.D.; Vicky Cho, X.L.; Closa, A.; Sutton, H.J.; Reed, J.H.; Bergmann, H.; Roots, C.M.; Yabas, M.; et al. Dysregulation of PAX5 causes uncommitted B cell development and tumorigenesis in mice. bioRxiv 2021. [CrossRef]

206. Rodriguez-Hernandez, G.; Hauer, J.; Martin-Lorenzo, A.; Schafer, D.; Bartenhagen, C.; Garcia-Ramirez, I.; Auer, F.; GonzalezHerrero, I.; Ruiz-Roca, L.; Gombert, M.; et al. Infection exposure promotes etv6-runx1 precursor b-cell leukemia via impaired h3k4 demethylases. Cancer Res. 2017, 77, 4365-4377. [CrossRef]

207. Bijl, J.; Sauvageau, M.; Thompson, A.; Sauvageau, G. High incidence of proviral integrations in the Hoxa locus in a new model of E2a-PBX1-induced B-cell leukemia. Genes Dev. 2005, 19, 224-233. [CrossRef]

208. Martin-Lorenzo, A.; Auer, F.; Chan, L.N.; Garcia-Ramirez, I.; Gonzalez-Herrero, I.; Rodriguez-Hernandez, G.; Bartenhagen, C.; Dugas, M.; Gombert, M.; Ginzel, S.; et al. Loss of pax5 exploits sca1-bcr-abl(p190) susceptibility to confer the metabolic shift essential for pb-all. Cancer Res. 2018, 78, 2669-2679. [CrossRef]

209. Hopkins, A.L.; Groom, C.R. The druggable genome. Nat. Rev. Drug Discov. 2002, 1, 727-730. [CrossRef]

210. Verdine, G.L.; Walensky, L.D. The challenge of drugging undruggable targets in cancer: Lessons learned from targeting bcl-2 family members. Clin. Cancer Res. 2007, 13, 7264-7270. [CrossRef]

211. Nasr, R.; Guillemin, M.C.; Ferhi, O.; Soilihi, H.; Peres, L.; Berthier, C.; Rousselot, P.; Robledo-Sarmiento, M.; LallemandBreitenbach, V.; Gourmel, B.; et al. Eradication of acute promyelocytic leukemia-initiating cells through pml-rara degradation. Nat. Med. 2008, 14, 1333-1342. [CrossRef] [PubMed]

212. De The, H.; Pandolfi, P.P.; Chen, Z. Acute promyelocytic leukemia: A paradigm for oncoprotein-targeted cure. Cancer Cell 2017, 32, 552-560. [CrossRef] [PubMed]

213. Conneely, S.E.; Stevens, A.M. Advances in pediatric acute promyelocytic leukemia. Children 2020, 7, 11. [CrossRef] [PubMed]

214. Benyoucef, A.; Palii, C.G.; Wang, C.; Porter, C.J.; Chu, A.; Dai, F.; Tremblay, V.; Rakopoulos, P.; Singh, K.; Huang, S.; et al. Utx inhibition as selective epigenetic therapy against tal1-driven t-cell acute lymphoblastic leukemia. Genes Dev. 2016, 30, 508-521. [CrossRef]

215. McMillin, D.W.; Delmore, J.; Weisberg, E.; Negri, J.M.; Geer, D.C.; Klippel, S.; Mitsiades, N.; Schlossman, R.L.; Munshi, N.C.; Kung, A.L.; et al. Tumor cell-specific bioluminescence platform to identify stroma-induced changes to anticancer drug activity. Nat. Med. 2010, 16, 483-489. [CrossRef]

216. Tabe, Y.; Konopleva, M. Role of microenvironment in resistance to therapy in aml. Curr. Hematol. Malig. Rep. 2015, 10, 96-103. [CrossRef]

217. Lane, S.W.; Scadden, D.T.; Gilliland, D.G. The leukemic stem cell niche: Current concepts and therapeutic opportunities. Blood 2009, 114, 1150-1157. [CrossRef]

218. Batsivari, A.; Haltalli, M.L.R.; Passaro, D.; Pospori, C.; Celso, C.L.; Bonnet, D. Dynamic responses of the haematopoietic stem cell niche to diverse stresses. Nat. Cell Biol. 2020, 22, 7-17. [CrossRef] 
219. Medyouf, H. The microenvironment in human myeloid malignancies: Emerging concepts and therapeutic implications. Blood 2017, 129, 1617-1626. [CrossRef]

220. Xia, B.; Tian, C.; Guo, S.; Zhang, L.; Zhao, D.; Qu, F.; Zhao, W.; Wang, Y.; Wu, X.; Da, W.; et al. C-myc plays part in drug resistance mediated by bone marrow stromal cells in acute myeloid leukemia. Leuk. Res. 2015, 39, 92-99. [CrossRef]

221. Sanchez-Aguilera, A.; Mendez-Ferrer, S. The hematopoietic stem-cell niche in health and leukemia. Cell. Mol. Life Sci. 2017, 74, 579-590. [CrossRef]

222. Passaro, D.; Quang, C.T.; Ghysdael, J. Microenvironmental cues for t-cell acute lymphoblastic leukemia development. Immunol. Rev. 2016, 271, 156-172. [CrossRef]

223. Calvo, J.; Fahy, L.; Uzan, B.; Pflumio, F. Desperately seeking a home marrow niche for t-cell acute lymphoblastic leukaemia. Adv. Biol. Regul. 2019, 74, 100640. [CrossRef]

224. Delahaye, M.C.; Salem, K.I.; Pelletier, J.; Aurrand-Lions, M.; Mancini, S.J.C. Toward therapeutic targeting of bone marrow leukemic niche protective signals in b-cell acute lymphoblastic leukemia. Front. Oncol. 2020, 10, 606540. [CrossRef]

225. Burt, R.; Dey, A.; Aref, S.; Aguiar, M.; Akarca, A.; Bailey, K.; Day, W.; Hooper, S.; Kirkwood, A.; Kirschner, K.; et al. Activated stromal cells transfer mitochondria to rescue acute lymphoblastic leukemia cells from oxidative stress. Blood 2019, 134, 1415-1429. [CrossRef]

226. De Smedt, R.; Morscio, J.; Reunes, L.; Roels, J.; Bardelli, V.; Lintermans, B.; van Loocke, W.; Almeida, A.; Cheung, L.C.; Kotecha, R.S.; et al. Targeting cytokine- and therapy-induced pim1 activation in preclinical models of t-cell acute lymphoblastic leukemia and lymphoma. Blood 2020, 135, 1685-1695. [CrossRef]

227. Gerby, B.; Hoang, T. A targetable cue in t-cell malignancy. Blood 2020, 135, 1616-1617. [CrossRef]

228. Ma, C.; Witkowski, M.T.; Harris, J.; Dolgalev, I.; Sreeram, S.; Qian, W.; Tong, J.; Chen, X.; Aifantis, I.; Chen, W. Leukemia-on-achip: Dissecting the chemoresistance mechanisms in b cell acute lymphoblastic leukemia bone marrow niche. Sci. Adv. 2020, 6, eaba5536. [CrossRef]

229. Tremblay, C.S.; Chiu, S.K.; Saw, J.; McCalmont, H.; Litalien, V.; Boyle, J.; Sonderegger, S.E.; Chau, N.; Evans, K.; Cerruti, L.; et al. Small molecule inhibition of dynamin-dependent endocytosis targets multiple niche signals and impairs leukemia stem cells. Nat. Commun. 2020, 11, 6211. [CrossRef]

230. Chattopadhyay, S.; Stewart, A.L.; Mukherjee, S.; Huang, C.; Hartwell, K.A.; Miller, P.G.; Subramanian, R.; Carmody, L.C.; Yusuf, R.Z.; Sykes, D.B.; et al. Niche-based screening in multiple myeloma identifies a kinesin-5 inhibitor with improved selectivity over hematopoietic progenitors. Cell Rep. 2015, 10, 755-770. [CrossRef]

231. Hartwell, K.A.; Miller, P.G.; Mukherjee, S.; Kahn, A.R.; Stewart, A.L.; Logan, D.J.; Negri, J.M.; Duvet, M.; Jaras, M.; Puram, R.; et al. Niche-based screening identifies small-molecule inhibitors of leukemia stem cells. Nat. Chem. Biol. 2013, 9, 840-848. [CrossRef] [PubMed]

232. Weng, A.P.; Millholland, J.M.; Yashiro-Ohtani, Y.; Arcangeli, M.L.; Lau, A.; Wai, C.; Del Bianco, C.; Rodriguez, C.G.; Sai, H.; Tobias, J.; et al. C-myc is an important direct target of notch1 in t-cell acute lymphoblastic leukemia/lymphoma. Genes Dev. 2006, 20, 2096-2109. [CrossRef] [PubMed]

233. Palomero, T.; Lim, W.K.; Odom, D.T.; Sulis, M.L.; Real, P.J.; Margolin, A.; Barnes, K.C.; O’Neil, J.; Neuberg, D.; Weng, A.P.; et al. Notch1 directly regulates c-myc and activates a feed-forward-loop transcriptional network promoting leukemic cell growth. Proc. Natl. Acad. Sci. USA 2006, 103, 18261-18266. [CrossRef] [PubMed]

234. Roderick, J.E.; Tesell, J.; Shultz, L.D.; Brehm, M.A.; Greiner, D.L.; Harris, M.H.; Silverman, L.B.; Sallan, S.E.; Gutierrez, A.; Look, A.T.; et al. C-myc inhibition prevents leukemia initiation in mice and impairs the growth of relapsed and induction failure pediatric t-all cells. Blood 2014, 123, 1040-1050. [CrossRef]

235. Yashiro-Ohtani, Y.; Wang, H.; Zang, C.; Arnett, K.L.; Bailis, W.; Ho, Y.; Knoechel, B.; Lanauze, C.; Louis, L.; Forsyth, K.S.; et al. Long-range enhancer activity determines myc sensitivity to notch inhibitors in t cell leukemia. Proc. Natl. Acad. Sci. USA 2014, 111, E4946-E4953. [CrossRef]

236. Jin, G.; Wong, S.T. Toward better drug repositioning: Prioritizing and integrating existing methods into efficient pipelines. Drug Discov. Today 2014, 19, 637-644. [CrossRef] 